\title{
False Assumptions: Military Assistance Command Vietnam's (MACV) Use of the Combined Strategic Objectives Plan, 1970 and its Operationalization at the Field Force Level
}

\author{
A Monograph \\ by \\ MAJ Ian M. Ginty \\ United States Army

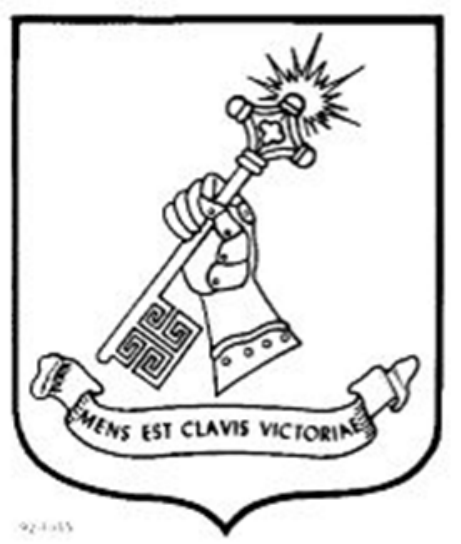 \\ School of Advanced Military Studies \\ United States Army Command and General Staff College \\ Fort Leavenworth, Kansas
}

AY 2014-02

Approved for public release; distribution is unlimited. 


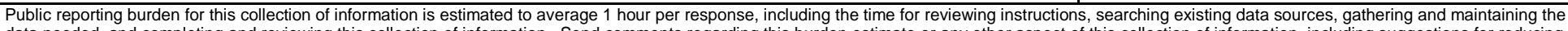

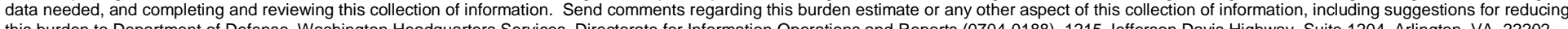

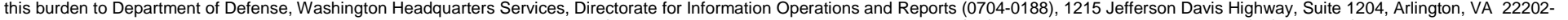

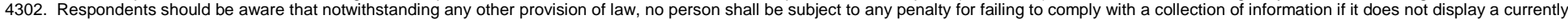
valid OMB control number. PLEASE DO NOT RETURN YOUR FORM TO THE ABOVE ADDRESS.

\begin{tabular}{l|l|l} 
1. REPORT DATE (DD-MM-YYYY) & 2. REPORT TYPE & 3. DATES COVERED (FrOm - TO)
\end{tabular}

04-12-2014

SAMS Monograph

JAN 2014 - DEC 2014

4. TITLE AND SUBTITLE

5a. CONTRACT NUMBER

False Assumptions: Military Assistance Command Vietnam's (MACV) use of the Combined Strategic Objectives Plan, 1970 and its Operationalization at the Field Force Level

\section{5b. GRANT NUMBER}

5c. PROGRAM ELEMENT NUMBER

6. AUTHOR(S)

Major Ian M. Ginty, U.S. Army

5d. PROJECT NUMBER

5e. TASK NUMBER

5f. WORK UNIT NUMBER

7. PERFORMING ORGANIZATION NAME(S) AND ADDRESS(ES)

School of Advanced Military Studies (SAMS)

8. PERFORMING ORGANIZATION REPORT

201 Reynolds Avenue

Fort Leavenworth, KS 66027-2134 NUMBER

9. SPONSORING I MONITORING AGENCY NAME(S) AND ADDRESS(ES)

Command and General Staff College

731 McClellan Avenue

Fort Leavenworth, KS 66027-1350

10. SPONSOR/MONITOR'S ACRONYM(S)

CGSC

11. SPONSOR/MONITOR'S REPORT NUMBER(S)

12. DISTRIBUTION / AVAILABILITY STATEMENT

Approved for Public Release; Distribution Unlimited

\section{SUPPLEMENTARY NOTES}

\section{ABSTRACT}

In 1970, Military Assistance Command Vietnam (MACV) published the Combined Strategic Objectives Plan (CSOP). This document was a collaborative effort that involved both the US Army planners and members of Republic of Vietnam's (RVN) Joint General Staff. The CSOP was an expansive document intended to detail the new operational approach General Creighton Abrams championed during his command of MACV. This operational approach departed from the previous "search and destroy" methology and sought fully to implement President Nixon's policy of “Vietnamization.” Abrams strategy was two fold and involved attacks against communist support networks while simultaneously putting much greater emphasis on the development of the South Vietnamese government and armed forces. For the CSOP and General Abrams’ new operational approach to work, however, two key assumptions would have to prove correct, the continued support of the American people and that the communists were unable or unwilling to mount a conventional invasion.

The CSOP provides an excellent case for analysis due to its thoroughness and breadth. It was not merely meant to cover the military aspects of the war effort, but to capture the effort at creating stable governance as well. However, due to its complexity it was also difficult to operationalize at the Field Force level, resulting in very little short term change to US Army operations.

\section{SUBJECT TERMS}

Vietnam, Operational Design, Operational Art, MACV, Field Force

\begin{tabular}{|c|c|c|c|}
\hline \multicolumn{3}{|c|}{ 16. SECURITY CLASSIFICATION OF: } & \multirow{2}{*}{$\begin{array}{l}\text { 17. LIMITATION } \\
\text { OF ABSTRACT }\end{array}$} \\
\hline $\begin{array}{l}\text { a. REPORT } \\
\text { Unclassified }\end{array}$ & $\begin{array}{l}\text { b. ABSTRACT } \\
\text { Unclassified }\end{array}$ & $\begin{array}{l}\text { c. THIS PAGE } \\
\text { Unclassified }\end{array}$ & \\
\hline
\end{tabular}

\begin{tabular}{c|l|}
$\begin{array}{c}\text { 18. NUMBER } \\
\text { OF PAGES }\end{array}$ & 19a. NAME OF RESPONSIBLE PERSON \\
\cline { 2 - 2 } 54 & $\begin{array}{l}\text { 19b. TELEPHONE NUMBER (include area } \\
\text { code) } \\
913-758-3302\end{array}$
\end{tabular}




\title{
Monograph Approval Page
}

Name of Candidate: $\quad$ MAJ Ian M. Ginty

Thesis Title: $\quad$ False Assumptions: Military Assistance Command Vietnam’s (MACV) use of the Combined Strategic Objectives Plan, 1970 and its Operationalization at the Field Force Level.

Approved by:

Dan C. Fullerton, Ph.D.

, Monograph Director

\author{
Dan C. Fulleiton, Ph.D.
}

Andrew Morgado, COL

, Seminar Leader

Henry A. Arnold III, COL

Director, School of Advanced Military Studies

Henry A. Arnold III, COL

\author{
Directo
}




\begin{abstract}
False Assumptions: Military Assistance Command Vietnam's (MACV) Use of the Combined Strategic Objectives Plan, 1970 and its Operationalization at the Field Force Level, by MAJ Ian M. Ginty, 54 pages.

In 1970, Military Assistance Command Vietnam (MACV) published the Combined Strategic Objectives Plan (CSOP). This document was a collaborative effort that involved both the US Army planners and members of Republic of Vietnam's (RVN) Joint General Staff. The CSOP was an expansive document intended to detail the new operational approach General Creighton Abrams championed during his command of MACV. This operational approach departed from the previous "search and destroy" methodology and sought fully to implement President Nixon's policy of "Vietnamization." Abrams' strategy was twofold and involved attacks against communist support networks while simultaneously putting much greater emphasis on the development of the South Vietnamese government and armed forces. For the CSOP and General Abrams' new operational approach to work, however, two key assumptions would have to prove correct, the continued support of the American people and that the communists were unable or unwilling to mount a conventional invasion.
\end{abstract}

The CSOP provides an excellent case for analysis due to its thoroughness and breadth. It was not merely meant to cover the military aspects of the war effort, but to capture the effort at creating stable governance as well. However, due to its complexity it was also difficult to operationalize at the Field Force level, resulting in very little short-term change to US Army operations. 


\section{Table of Contents}

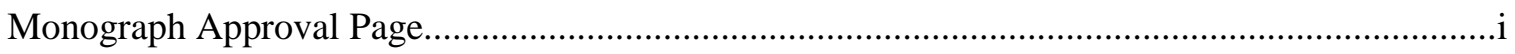

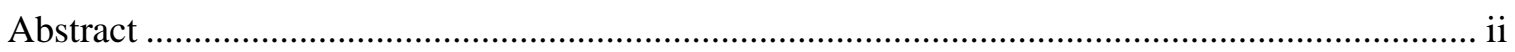

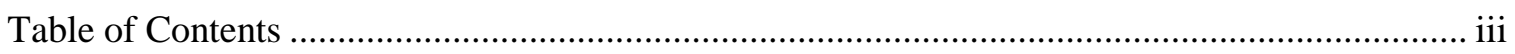

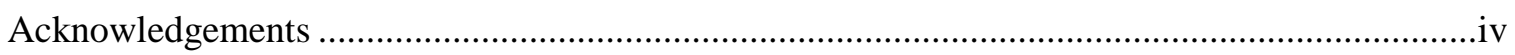

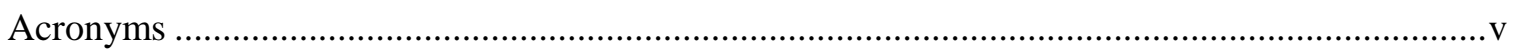

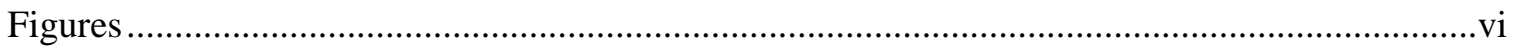

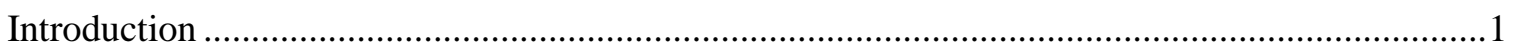

Operational Environment and Strategic Context, 1970 ............................................................

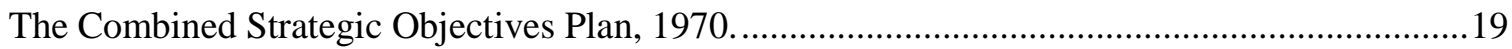

Corps and Division Military Operations in support of the Combined Strategic Objectives Plan,

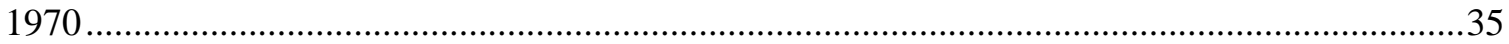

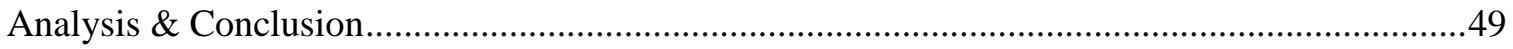

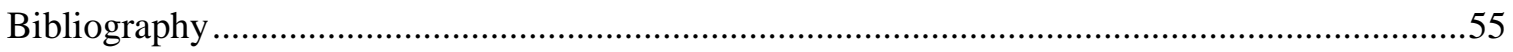




\section{Acknowledgements}

The utmost thanks to Dr. Dan Fullerton and COL Andrew Morgado for their excellent guidance and the prodigious editing that helped make my thoughts intelligible. I would also like to thank my mother for using the skills and tact from her lifetime as an educator to help me refine my thoughts and to my father whose experience in Vietnam inspired me to write about this topic.

Finally, I would like to thank my wife, Kerry, for her patience, restraint, and support, allowing me the exorbitant amount of time I needed in seclusion to grind through this project. 


\section{Acronyms}

\begin{tabular}{|c|c|}
\hline ARVN & Army of the Republic of Vietnam \\
\hline CIA & Central Intelligence Agency \\
\hline COSVN & Central Office South Vietnam \\
\hline CORDS & Civil Operations and Rural Development Support \\
\hline CSOP & Combined Strategic Objectives Plan \\
\hline CTZ & Corps Tactical Zone \\
\hline DOD & Department of Defense \\
\hline DRV & Democratic Republic of Vietnam \\
\hline $\mathrm{FF}$ & Field Force \\
\hline FWMAF & Free World Military Assistance Forces \\
\hline GVN & Government of Vietnam (Referring to the Republic of Vietnam) \\
\hline JGS & Joint General Staff (Republic of Vietnam) \\
\hline LOE & Line of Effort \\
\hline MACV & Military Assistance Command Vietnam \\
\hline NVA & North Vietnamese Army \\
\hline $\mathrm{PF}$ & Popular Forces \\
\hline OCO & Office of Civil Operations \\
\hline $\mathrm{RDC}$ & Rural Development Cadre \\
\hline $\mathrm{RF}$ & Regional Forces \\
\hline RVN & Republic of Vietnam \\
\hline RVNAF & Republic of Vietnam Armed Forces \\
\hline US & United States \\
\hline VC & Viet Cong \\
\hline VCI & Vietnamese Communist Infrastructure \\
\hline
\end{tabular}




\section{Figures}

1 MACV and JGS planners forecast the need for a US troop presence in Vietnam into 1980. In the short term, they planned to have between 50,000 and 100,000 US troops in Vietnam until mid-1976.

2 Graphic depiction of friendly operations and force flow as objectives are achieved.....27

3 The above graphic shows the massive inflation and de-evaluation of the RVN piaster in comparison to the US dollar. This caused significant issues for the GRVN, particularly when it came to paying government employees and troops..........................................31

$4 \quad$ Map depicting the Corps Tactical Zones (CTZ), provincial, and national boundaries of the RVN. The numerical designations for CTZs do not match the numerical designation for the various corps level commands operating in those areas. I Field Force operated in the II CTZ and II Field Force operated in the III CTZ as indicated above.

5 Map depicting economic activity and farming in the RVN. This shows why the southern portion of the RVN was vital to both the communists and the GVN. 


\section{Introduction}

The indirect threat to the United States (US) provided by communist aggression in eastAsia during the 1950s and 1960s created a situation in which the alignment of political aims and military objectives were be both challenging to balance, yet critical to obtaining a successful resolution. In the book, Historical Perspectives of the Operational Art, authors Cody Phillips and Michael Krause argue that that Vietnam War was lost due to a such a misalignment of political and military aims and that US was lacking “...a coherent strategy and the operational objectives that might have supported it.” ${ }^{1}$ In line with this assessment, the US lost the war in Vietnam because the new operational approach, promulgated under General Creighton Abrams in 1970, was based on fatal assumptions that never became fact, due to a tragic disconnect between the military planners and the domestic political reality. The war in Vietnam is widely considered a war of choice in which US vital national interests were only indirectly threatened through a tenuous linkage to the worldwide spread of communism. ${ }^{2}$ Wars of choice complicate the interplay between the military and political apparatus of any nation. ${ }^{3}$ Political and military objectives can run contrary to each other; the civil's need to limit destruction, regulate the use of force, and maintain popular support can run contrary to the military's need to defeat enemy forces and protect its own means of war making. These considerations affect the development of the operational approach a military commander must choose to pursue their objectives.

${ }^{1}$ Center of Military History, United States Army, Historical Perspectives of the Operational Art (Fort McNair: Government Printing Office, 2005), 329.

${ }^{2}$ Richard Haas, War of Necessity, War of Choice: A Memoir of Two Iraq Wars (New York: Simon and Schuster, 2009), 273-274.

${ }^{3}$ American diplomat Richard Haas acknowledges that the determination of the necessity of a particular war is a subjective one but he generally defines a war of choice as any war fought when other alternatives remain available, Ibid., 1-16. 
The right operational approach must be developed in order to achieve the desired end state in any conflict. Joint Publication 5-0, Joint Operations, defines an operational approach as “...a description of the broad actions the force must take to transform current conditions into those desired at the end state.”4 An operational approach provides guidance to allow subordinates and planners to understand how to sequence tactical actions to the overall plan that achieves the end state. This becomes a framework for action. An operational approach must be clearly articulated, understood, and actionable by those tactical level units that will be executing them. The correct sequencing of tactical actions to meet strategic aims is operational art.

The proper use of operational art is the pinnacle of military achievement in any armed struggle. Army Doctrine Reference Publication 3-0, Unified Land Operations, states that, “...for Army forces, operational art is the pursuit of strategic objectives, in whole or in part, through the arrangement of tactical actions in time, space, and purpose.”5 Operational art displays a synergy between the military and political aims of a force in conflict, which aligns the military objects with the goals of the body politick. In theory, this whole of government approach creates a unity of effort that will more easily overwhelm an adversary and bring victory. Operational art is difficult to achieve and requires a complete understanding of a myriad of friendly and enemy political, military, environmental, and temporal variables that are ever changing. There are many potential points of failure between the current conditions and the desired future conditions that can frustrate the achievement of victory. ${ }^{6}$ Even by achieving all military objectives, the political

${ }^{4}$ Joint Staff, Joint Publication 5-0, Joint Operations (Suffolk: Government Printing Office, 2011), GL-13.

${ }^{5}$ Army Doctrine Reference Publication (ADRP) 3-0, Unified Land Operations (Washington, DC: Government Printing Office, 2012), 4-1.

${ }^{6}$ Ibid., 4-1. 
endstate may remain elusive. The very premise upon which military operations are based can be flawed from its inception, creating an unachievable political endstate. Likewise, military objectives may be misaligned with the desired political endstate, creating an environment in which war is fought for its own sake with little consideration for the feasibility of its continued execution. $^{7}$

The Vietnam War is one such case where the misalignment of political and military objectives led to a flawed operational approach. This seemed to remain the case even in 1970 when the Combined Strategic Objectives Plan (CSOP) provided clearly articulated direction, which attempted to align political and military objectives. This document was the result of extensive analysis and planning on the part of both the US and South Vietnamese militaries and governments. ${ }^{8}$ If the CSOP, 1970 successfully aligned military objectives with national aims at what point did the strategy fail? ${ }^{9}$ As previously stated, there are many potential points of failure in the application of operational art. Clearly stated political objectives could simply be the wrong objectives to pursue, basing any further military execution on a false premise. Likewise, military

${ }^{7}$ The Japanese military's prosecution of the war in the Pacific is such an example. According to the prolific Japanese author of history and philosophy, Saburo Ienaga, the very structure of the Japanese government following the development of the General Staff and the adoption of the Meiji Constitution allowed the military nearly unchecked power and autonomy. He explains this in his book The Pacific War, 1931-1945, which was originally published in Tokyo by IWANAMI SHOTEN, in 1968, at great length. The political body of the Japanese government was kept completely ignorant of military operations and aims, while even the separate branches of the armed services kept their operations secret from one another. This resulted in a military coup, circumventing civilian political attempts to moderate violence by manufacturing incidents that justified war.

${ }^{8}$ Headquarters MACV, The Combined Strategic Objectives Plan, 1970 (Operational Planning and Directives, San Francisco: Headquarters MACV, 1970), 2.

${ }^{9}$ In the introductory memorandum for the CSOP the MACV Chief of Staff, Major General W.G. Dolvin states, “A broad, solid platform finally has been developed on which all other plans can rest; goals are stated, threats identified, and thrusts, broad enough to cover the military, political, economic and socio-psychological aspects of the war, examined”, Ibid., introductory transmittal memorandum. 
objectives could be misaligned with the political purpose. Even the pursuit of those objectives could be flawed by an operational approach that fails to achieve them. Even if both military and political objectives are properly aligned, the methods used by the military to achieve them could have proven counterproductive, resulting in defeat.

This monograph will explore the failure of the CSOP to bring victory to Coalition forces fighting in Vietnam. ${ }^{10}$ It will seek to determine if the CSOP provided a clear alignment of objectives from the strategic to the tactical. Additionally, this monograph will focus on the operational approach described by the CSOP and the way it sought to sequence tactical actions to achieve the desired end state and how subordinate commands internalized and translated this operational approach into action. The CSOP, 1970 will be examined to determine the feasibility of its baseline assumptions for planning to identify any critical imperfections that may have existed that prevented it from being successfully executed, resulting in a flawed operational approach.

The methodology that will be used for analysis will be a comparison of available primary source documents consisting of quarterly operational and after action reports both before and after the publication of the CSOP, 1970. This will be done by conducting an analysis of the CSOP itself and then analyzing the execution of the CSOP by tactical and operational level units. ${ }^{11}$ The tactical and operational level units to be examined will be at the division and corps level with

${ }^{10}$ The Coalition of nations supporting the Republic of Vietnam consisted of nearly 30 nations. Australia, New Zealand, Thailand, and the Republic of Korea provided combat troops while other nations provided various levels of assistance.

${ }^{11}$ Where possible corps reports will be used as the primary means to assess the internalization and execution of the CSOP 1970. Where corps reports are unavailable of division reports will act as the primary source. In order to maintain perspective, division reports from all corps areas will be examined. The only CTZ that will not be assessed is CTZ IV, the far southern tip of the RVN. This region had virtually no US presence at the time. Corps reports are available for I and II Field Force. Records of III Field Force reports were unavailable for the period being covered. 
some analysis of the reporting and operations of separate brigades. ${ }^{12}$ If the operational approach in the CSOP, 1970 was adopted properly by the corps' and divisions, their after action reports should reflect this through changes in structure and emphasis.

This document will be broken into several sections for clarity. The first section will describe the context of the publication of the CSOP; the then-current state of the war in Vietnam as this document was being developed will be described. Following this, the CSOP itself will be examined. The focus of this analysis will be on the operational approach within the CSOP. The next sections will review the actions of subordinate units at the corps and division level to determine how they adopted the operational approach described in the CSOP. The final section of this monograph will conclude with an analysis of unit actions in support of the CSOP to attempt to determine the effect the publication of the CSOP had on the tactical actions of subordinate units.

This research will focus on how the CSOP, 1970 was put into action by units operating throughout Vietnam. While this was a triumph in coalition military planning due to its broad scope and the approval of both US and Vietnamese military and political arms, its true test would be in the operationalization of this effort into actions on the ground. This monograph will focus on the military aspects of the CSOP; these, however, will be balanced against the political objectives that the military efforts support. Both the United States (US) and Republic of Vietnam (RVN) political objectives will be considered. As the CSOP was superseded by an updated annual document, the primary effort of this research will be to examine the manner in which the objectives that were outlined as "Immediate" were operationalized. The objectives classified as

${ }^{12}$ The term corps and field force will be used interchangeably throughout this monograph. Both terms refer to essentially the same thing. The field force headquarters were enlarged corps headquarters that supervised, directed, and coordinated the activity of numerous subordinate divisions and separate brigades throughout the CTZs. 
"Intermediate" and "Ultimate" will be used to inform the evaluation of the effort to realize the immediate objectives.

Despite the thorough planning and the support of both the military and political arms directly involved in the war in Vietnam, the CSOP failed to deliver the promise of a stable and legitimate RVN. The eventual fall of the RVN was a result of political objectives that were unrealistic, due to false assumptions within the CSOP, 1970 itself. This failure manifested itself in a misreading of both domestic and international sentiment towards the war and a military's pursuit of these objectives that further exacerbated an already tenuous political situation. While the CSOP clearly dictated a new operational approach to the war, it did not achieve a uniform effect on the operations of subordinate commands. The false assumptions inherent in the new operational approach embodied by the CSOP, 1970, created unattainable goals for MACV, that the command was unable to realize while under stress and in contact with the enemy. 


\section{Operational Environment and Strategic Context, 1970}

After the massive losses to Viet Cong (VC) communist insurgents during the 1968 Tet Offensive, the war in Vietnam was in transition. ${ }^{13}$ Field Manual 3-24, C1, Insurgencies and Countering Insurgencies explains that an insurgency, “....is a struggle for control and influence, generally from a position of relative weakness, outside existing state institutions.” ${ }^{14}$ The communist insurgency was operating more from a "position of relative weakness" after the failure of the Tet offensive than before. During Tet, the VC had borne the brunt of the fighting and were virtually eliminated as a fighting force. The communist goal of creating a popular uprising in the RVN had failed militarily, thereby destroying the communist insurgent infrastructure that had been carefully cultivated in South Vietnam for years. The loss of some 48,000 VC during the Tet Offensive forced North Vietnam to infiltrate large numbers of troops and revolutionary cadre into the south in order to maintain the viability of the insurgency. The Northern communists, however, were no replacement for the homegrown insurgents that had been lost during Tet. These North Vietnamese Army (NVA) regulars did not know the people nor the terrain in areas in which they operated. This forced the NVA to rely on greater levels of coercion, not only in order to spread their ideology, but also to maintain support. Perhaps one of the most operationally significant factors to the replacement of VC by the NVA was the massive logistics tail that would now be required to keep the NVA troops dispersed across the RVN fed, clothed, and armed. While the VC had been reliant on the North primarily for weapons alone, due

${ }^{13}$ Reports to the Chairman of the Joint Chiefs of Staff from MACV in February 1968 estimated communist losses during the Tet Offensive at 40,000 killed, 3,000 captured, and another 5,000 disabled or died of wounds, James H. Wilbanks, The Tet Offensive: A Concise History (New York: Columbia University Press, 2007), 208.

${ }^{14}$ Field Manual (FM) 3-24, C1, Insurgencies and Countering Insurgencies (Washington, DC: Government Printing Office, 2014), 1-1. 
to their ability to live off the local population within their area of operations, the NVA were foreigners who enjoyed no such advantage. This necessitated that all classes of supply be delivered to them and that in particular feeding the NVA would be a problem. ${ }^{15}$ The local communist insurgency remaining within the RVN was largely defeated. The VC had been the primary political instrument of the politico-military aspect of the communist struggle against the RVN, and with their demise, the Northern communists would struggle to rebuild insurgent infrastructure while maintaining their fielded forces at the extremes of their operational reach. While US troop strength peaked in 1968 at over half a million men under the Lyndon Johnson administration, President Richard Nixon won the election on his pledge to end the war. According to A Companion to the Vietnam War, Nixon "softened his Cold warrior image and made frequent promises on the campaign trail of a 'secret plan for peace'.”16 Troop withdrawal would begin in 1969 and continue steadily until the end of the war. US involvement in Vietnam had become so divisive domestically that it had effectively ended the Johnson administration. The American public had little support for the war and what support remained, continued to wane. In December 1969, just days after taking office, President Nixon announced that the war in Vietnam was ending. His plan to end the war was termed "Vietnamization," a strategy to end direct US participation in the war in Vietnam. ${ }^{17}$ In the words of President Richard Nixon: “...I changed General Abrams' orders so that they were consistent with the objectives of our new policies. Under the new orders, the primary mission of our troops is to enable the South Vietnamese forces

${ }^{15}$ James H. Wilbanks. Vietnam War: The Essential Reference Guide. Santa Barbara : ABC-CLIO, 2013, 3.

${ }^{16}$ Blackwell Publishing, A Companion to the Vietnam War (Malden: Blackwell Publishing Company, 2002), 261.

${ }^{17}$ Jeffrey J. Clarke, Advice and Support: The Final Years, The U.S. Army in Vietnam (Washington DC: Government Printing Office, 1988), 341. 
to assume the full responsibility for the security of South Vietnam.” ${ }^{18}$ This strategy required a renewed emphasis on the recruitment, training, and equipping of South Vietnamese security forces. As the Army of the Republic of Vietnam (ARVN) units became combat ready, they would rapidly assume responsibility across the RVN from US troops, while the South Vietnamese government also increased in capacity and proficiency. The intent of this was to permit the orderly withdrawal of US forces that was another major component of "Vietnamization.” ARVN would step forward and the US Army would step backward. The belief was that as RVN security forces became more proficient and confident, an increasing number of US troops could rotate home, thus decreasing the American commitment of personnel to Vietnam. These principles in concept remain consistent with current US Army counterinsurgency doctrine. Army Field Manual 3-24, C1, Insurgencies and Countering Insurgencies states:

The use of security cooperation tools to build governmental capability, including building a host nation's forces, may be essential. In the eyes of a local population, the credibility of the host-nation government is vital in counterinsurgency efforts to address the threat and conditions of instability. The host nation's military, police, and paramilitary forces are often the most visible elements of a host-nation government's power and authority. Therefore, building the capacity of a host nation's security forces should work toward improving the security force's competence, capability, commitment, and confidence. ${ }^{19}$

The Nixon administration's analysis revealed that there were no good options in Vietnam, so they sought the most expeditious means to disentangle the US from the war. ${ }^{20}$ As the new presidential administration was determined to wind down US involvement in Vietnam, the

${ }^{18}$ Richard Nixon, Public Broadcasting System, The American Experience, November 03, 1969, accessed September 11, 2014.

http://www.pbs.org/wgbh/americanexperience/features/primary-resources/nixon-vietnam/.

${ }^{19}$ FM 3-24, C1, 11-1.

${ }^{20}$ Michael A. Eggleston, Exiting Vietnam: The Era of Vietnamization and American Withdrawal Revealed in First-Person Accounts (Jefferson: McFarland and Company Inc., Publishers, 2014). 
Military Assistance Command Vietnam (MACV) leadership realized that their time to make progress was growing short. ${ }^{21}$ Both the US and communist plans were in a period of transition. The communist transition to a war effort increasingly reliant on external support, created new opportunities for coalition forces, allowing the US and the Government of the Republic of Vietnam (GVN) to reevaluate their operational approach, which up to this point had been generalized as "search and destroy.” General William Westmoreland himself had stated that, “There was no alternative to 'search and destroy' type operations, except, of course, a different name for them.”22 Enhancing the opportunity for transition was General Creighton Abrams, the new MACV commander, who was determined to ensure that the way ahead in Vietnam was clear and that unity of effort between both the US and Republic Vietnam Armed Forces (RVNAF) and GVN was improved. The military and political conditions were right to change how the Coalition forces had been fighting the war, by creating a more independent and self-sufficient ARVN that could take over the fighting from the US forces.

The US Army, up to this point, conducted the war in an enemy-focused manner. The term “search and destroy” was synonymous with the operational approach taken during General William Westmoreland's command of MACV, an approach that sought to destroy enemy fighters, formations, and war materiel. ${ }^{23}$ It was necessary to fight the war in this way because until the Tet Offensive in 1968, the Viet Cong and NVA, remained immediate vital threats to the survival of the RVN. General Westmoreland's belief was that this threat had to be met in a direct

${ }^{21}$ The realization that time was short is evident throughout the CSOP as time is consistently referenced as a critical factor to winning the war.

${ }^{22}$ Harry G. Summers, On Strategy: A Critical Analysis of the Vietnam War (New York: Random House Publishing, 1982), 175.

${ }^{23}$ Ibid., 174. 
manner. ${ }^{24}$ While General Westmoreland recognized the danger posed by the large conventional units of the NVA and the VC guerrillas, the purpose of search and destroy was to focus US efforts on the large NVA formations. This was done to allow the RVNAF to provide the population of South Vietnam, “[S]ecurity from the guerrillas, the assassin, the terrorist, and the informer." ${ }^{25}$ General Westmoreland used a now famous analogy to describe both threats the RVN faced. He referred to the NVA conventional forces as "bully boys with crowbars" and to the VC as "termites.” Both could destroy the "house” that was Vietnam, but the "bully boys” were the more dangerous of the two in the short term and must be dealt with first. ${ }^{26}$ This strategy, played to the strengths of both the RVNAF and the US; the RVNAF were better able to root out insurgents and secure their own people, while the US military had the combat power to defeat NVA incursions. While acknowledging that the greatest threat to the RVN was an external one in the form of invasion from Democratic Republic of Vietnam (DRV), political guidance ruled that any expansion of major ground combat operations to neighboring neutral states was to be absolutely avoided. ${ }^{27}$ Expanding the war beyond the borders of the RVN could have been politically damning both abroad and domestically. At home in the US, the war in Vietnam was already losing support; the war decreased in popularity as it dragged on. Due to the growing unpopularity of US commitment in Vietnam, domestic US politics were a major consideration

${ }^{24}$ Gregory A. Daddis, No Sure Victory: Measuring U.S. Army Effectiveness and Progress in the Vietnam War (New York: Oxford University Press, 2011), 91.

${ }^{25}$ Mike Gravel, Noam Chomsky, Howard Zin, The Pentagon Papers: The Senator Gravel Edition (Boston: Beacon Press, 1971), 606.

${ }^{26}$ Ibid., 606.

${ }^{27}$ Timothy N. Castle, At War in the Shadow of Vietnam: US Military Aid to the Royal Lao Government 1955-1975 (New York: Columbia University Press, 1993), 93. 
influencing any significant decisions by the coalition. ${ }^{28}$ This constrained MACV to fighting almost exclusively on South Vietnamese soil, in a purely defensive fight.

Disapproval for the war in Vietnam was growing among Americans, as was evident by the defeat of Hubert Humphries’ candidacy during the 1968 election and the growing number of protests nation-wide. The Johnson administration had sought to mitigate the political costs of the war by putting limits on US involvement wherever possible. The need to limit US involvement and at the same time defeat communist forces created friction between what was politically manageable and what was militarily sensible. The Tet Offensive while disastrous for the communists militarily had incredible political value due to the shock felt by Americans, who had been told that the war was all but won. The result being that the resolve of the US electorate to continue fighting in Vietnam was rapidly declining. ${ }^{29}$ The American public was no longer willing to believe the military's press releases from Vietnam as the “credibility gap” widened.

Because of the geographical limits placed on US operations, Laos and Cambodia became significant bases for the sustainment and direction of the communist forces that were politically beyond the reach of the US. This allowance for enemy safe areas meant that communist forces could continue to project power into the RVN along a densely forested and mountainous border that was impossible for Coalition forces to control. The communists did not recognize regional

${ }^{28}$ The increasing disquiet of the American electorate due to the Vietnam War is a repeating theme in the CSOP. As a consideration for the US strategy page eight states, "Increasing domestic pressure in the United States to reduce the expenditure of resources caused by the US commitment to the effort in Vietnam will cause a decline in the overall level of resources available. This factor may contribute to the requirement for a change in tactics to support the new strategy, and to future adjustments in the strategy of the struggle”, Headquarters MACV, The Combined Strategic Objectives Plan, 1970, Operational Planning and Directives, San Francisco: Headquarters MACV, 1970, 8.

${ }^{29}$ Dale C. Walton, The Myth of Inevitable US Defeat in Vietnam (New York: Frank Cass Publishers, 2002), 34. 
national boundaries as any inhibitor to their operations, signifying that the war in Vietnam was a regional conflict despite the lack of willingness to treat it as such by US leadership.

At the theater level, MACV planners struggled to conceptualize an operational approach that would preserve the existence of South Vietnam with a government politically acceptable to both the American public and the South Vietnamese. Just as difficult, if not more so, would be the challenge to redirect a massive military apparatus, of over 500,000 US troops alone, in a fundamentally new direction. This would have to be accomplished in stride, while still engaged with a tenacious and cunning enemy. After serving as General Westmoreland's deputy in 1967 and into 1968, General Creighton Abrams took command of MACV as Westmoreland was selected to be the Army Chief of Staff. In early 1969, MACV published an objectives plan that outlined in broad terms General Abrams’ current assessment of the mission in Vietnam, the desired endstate, and the operational approach the Coalition would use to get there. This plan would form the basis for extensive analysis that would lead to the development of a much more comprehensive plan to come.

Abrams gave a grim assessment of the war of which he had just taken command. The MACV Objectives Plan, 1969 clearly echoed the frustration of both the military and the American public; the most important commodity to the coalition forces and the insurgent was “time.” ${ }^{30}$ In Abrams' assessment, he determined that the patience of the American people be preserved to ensure that US departure from the RVN was not so hasty as to facilitate communist victory, but not so slow as to prevent the South Vietnamese from doing for themselves what the Coalition had been doing for them for years. He believed it was time for the GVN to manage its own security and take over the bulk of the war fighting. This document leveled scathing criticism at the GVN, firmly placing nearly all the blame for the lack of progress on them. The

${ }^{30}$ Headquarters MACV, Commander's Summary of the MACV Objectives Plan, Commander's Summary, (Saigon: HQ MACV, 1969), 3. 
Commander's Summary of the MACV Objectives Plan stated the following, "Thus far, the GVN has proved unwilling or incapable of undertaking many of the actions the US deems necessary to improve its performance. This poses a particular problem, for it is only through GVN performance that US objectives can be achieved.” ${ }^{31}$ Clearly, MACV planners had determined that while the communists were a constant threat, the real problem was the South Vietnamese unwillingness to reform. ${ }^{32}$

The GVN, however, was not solely to blame. The same document stated that much of the failure of the GVN was due to a lack of continuity and unity of effort amongst the Coalition. ${ }^{33}$ The Coalition mission in Vietnam was disorganized. MACV had failed to delineate clearly responsibility for the differing LOEs meant to reinforce and develop the GVN. Likewise, MACV had not clearly stated its objectives or provided guidance on how to achieve them. Abrams was determined to correct this through the issuance of clear guidance, creating unity of effort, and by putting the GVN in the lead, allowing the US to continue withdrawal. To achieve this, in February 1970, MACV published the Combined Strategic Objectives Plan (CSOP). This was the product of a combined planning effort between the GVN and MACV that outlined the way ahead for the prosecution of the war. This plan, which was a MACV initiative, sought to put a welldefined purpose behind US involvement in Vietnam and to create unity of effort within a multidisciplinary approach that would attempt to remove the sources of instability within the RVN and to defeat the communist war effort.

The CSOP embodied a new direction for the US war effort. It echoed President Nixon's plan to "Vietnamize" the war, while targeting communist forces where they were weakest. It
${ }^{31}$ Ibid., 4.
32 Ibid., 4.
${ }^{33}$ Ibid., 4-5. 
emphasized governance and the indirect defeat of communist forces by destroying their logistics and support apparatus. It de-emphasized the direct engagement and the destruction of enemy forces that had been a hallmark of previous MACV efforts, thus representing a major change in not only how MACV would conduct the war, but also how the war was understood and perceived by the US commanders. ${ }^{34}$ What had already been America's longest war was recognized in the CSOP as a struggle that could run in perpetuity if not managed properly, while also recognizing that the patience and support of the American people was nearing the end of its endurance. President Nixon was determined to get the US disentangled from the war and by this time, virtually nothing would stop the steady withdrawal of US troops. ${ }^{35}$ None of the possible futures outlined in the CSOP were clear wins for the RVN, as MACV planners readily identified that the struggle in Vietnam would continue long after the withdrawal of US combat units.

${ }^{34}$ Ibid., 3.

${ }^{35}$ Lewis Sorley, A Better War: The Unexamined Victories and the Final Tragedy of America's Last Years in Vietnam (Orlando: Harcourt, Inc., 1999), 116. 


\section{The Combined Strategic Objectives Plan 1970}

The Combined Strategic Objectives Plan of 1970 was a comprehensive 199-page document that covered a wide breadth of topics pertinent to the prosperity and security of the RVN. MACV and the Vietnamese Joint General Staff (JGS) developed this document against the backdrop of an impending US troop withdrawal. ${ }^{36}$ This was the first such document that developed by both the US and the RVNAF, working together to define the problem they faced and to develop an operational approach that would defeat communist forces. It created a common language and issued broad guidance to military commanders, while it sought to inform US civilian leadership of the risks and opportunities pertinent to this conflict. The CSOP attempted to tie ends, ways, and means together while trying to make a realistic assessment of the commitment necessary to defeat communist efforts in Vietnam. This document contained incredibly thorough analysis and provided clear language to conduct assessments of progress. The CSOP indicated that a US presence would be necessary until the 1980's before the GVN was truly secure from a communist threat. ${ }^{37}$ While not necessarily unrealistic, a key component to this operational approach was that the RVNAF rapidly improved in capability and competence.

The goal of Coalition efforts in the RVN were “...to build a free, independent, and viable nation in South Vietnam.”38 The development of the CSOP 1970 was finally an acknowledgement the struggle against communist forces would not end quickly. This acknowledgement, though, came after US forces had already been fighting in Vietnam for six years. During this time, there had been no basis upon which to define the relationship between the

\footnotetext{
${ }^{36}$ Headquarters MACV, The Combined Strategic Objectives Plan, 1970, CommanderMACV's opening memorandum.

${ }^{37}$ US troop levels in this regard are discussed later in this paper. See Figure 3 for a graphic depiction of estimated US involvement into the 1980's.

${ }^{38}$ Headquarters MACV, The Combined Strategic Objectives Plan, 1970, 6.
} 
US and the RVN. Coordination between the two governments and militaries existed but was mainly the result of efforts to achieve tactical goals. The purpose of the CSOP was stated as “...to meet the demands of this situation, by providing a common strategy to enable execution of a more prolonged course of action, and to provide the required bilateral - eventually multilateral guidance for the Allied forces.”39 After six years of war in Vietnam, the seven nations fighting there and the forty-three nations providing assistance in one form or another, still lacked unity of action. ${ }^{40}$ The CSOP meant to provide this.

MACV's new plan outlined the conditions by which the "struggle" in Vietnam would continue. MACV planners were aware that to Central Office for South Vietnam (COSVN), "The South Vietnam Revolution is an integral part of the world revolution." ${ }^{41}$ Communist forces in South East Asia did not view the war against coalition forces in the RVN as a closed struggle, but instead as a part of a regional conflict to include Laos and Cambodia. The communist forces also understood the value of ideas and narrative to create a system of continuous struggle against anticommunist forces. $^{42}$

As MACV continued to develop the scope of the struggle in Vietnam by defining US efforts as an attempt to prolong the existence of the RVN; they were purely defensive and ultimately aimed at the construction of a stable government in the RVN that was capable of resisting communist subversion. Even if a cease-fire did occur, the struggle between the DRV and

${ }^{39}$ Ibid., 6.

${ }^{40}$ Nations that had provided significant numbers of troops to assist the RVN in the fight against the communists included the US, the Republic of Korea, Australia, New Zealand, Thailand, and the Philippines, LTG Stanley Robert Larsen and BG James Lawton Collins, Jr. Allied Participation in Vietnam (Washington, DC: Government Printing Office, 1985).

${ }^{41}$ Headquarters MACV, The Combined Strategic Objectives Plan, 1970, 30.

${ }^{42}$ Ibid., 30. 
the RVN would continue in perpetuity. This was a regional struggle between communist dictatorship and free democracy, supported by external actors, which hinged directly upon the success or failure of Coalition efforts in Vietnam. While the destruction of the DRV was not an overt consideration, MACV and JGS planners made allusions to the eventual reunification of both halves of Vietnam. ${ }^{43}$ This was stated as a strategic political objective of the GVN, but was consistently mentioned as being achieved through a democratic process as opposed to conquest.

The CSOP expanded its purpose and scope in the "Strategic Guidance" section, particularly in the discussion of "Tu Tuong," which is interpreted as a "thoughtful understanding.” Above all else, this section wrestled with the many and varied interests and audiences that existed with respect to the war. The passages devoted to the development of Tu Tuong were dual purposed, seeking to create unity of purpose and effort by the promulgation of a narrative conducive to the support of the GVN. At the same time, it also is a counter message to the communist narrative. Both the stated objectives expressed in DRV and RVN narratives were essentially the same, calling for the promotion of independence, freedom, democracy, and peace. However, the MACV planners attempted to link communist ways to violence and coercion versus the RVN's emphasis free choice. ${ }^{44}$ This section thus discussed the best way to "indoctrinate" the people of the RVN to unite against communism and explained that the national constitution must be the ideology of the nation.

The last line in the summary of Tu Tuong was telling, when it stated, “Although each person is to have his own philosophy, the basis of the national thought must be related to the Constitution.” 45 This statement is as important for what it says as for what it does not. The

$$
\begin{aligned}
& { }^{43} \text { Ibid., } 88 . \\
& { }^{44} \text { Ibid. } \\
& { }^{45} \text { Ibid., } 123 .
\end{aligned}
$$


Constitution embodies the way that the Vietnamese should think about their nation. It does not say that the Constitution should be the embodiment of the way the Vietnamese view the role of their government and their place in it. The sub-section dealing with the "Building of Military Tu Tuong” was not so much guidance, as it was an in depth description of a desired utopian military end state, in which senior leaders were able to “...thoroughly understand [military and political] concepts and provide real leadership in these areas.”46 The lowest ranked soldier should understand these policies as well, thus seeing the value in them and "...act on them vigorously and devotedly.” This section borrowed heavily from western military philosophy, with an entire paragraph dedicated to the relationship between war and policy, and being absolutely Clauswitzian in its description of the nesting of military objectives to support political purpose. This concept, however, should have been familiar to the South Vietnamese through the writings of Mao Tse-tung, which directly influenced the thoughts of the communist forces. ${ }^{47}$ Likewise, the American interpretation of military subordination to civil government was stressed. Unlike the American ideals of the apolitical serviceman, however, the Vietnamese ideal was a soldier imbued with political purpose that flowed from the central government and the Constitution. The creation of narrative and national identity amongst the South Vietnamese was the umbrella under which the individual LOEs existed.

In the Strategic Concept section, the CSOP described the philosophy of the future conduct of the war while redressing prior criticisms of the same. The primary purpose of all activity conducted by military forces was reinforced as the “...provision of effective security for

${ }^{46}$ Ibid., 120.

${ }^{47}$ Antulio J. Echevarria II, Clausewitz and Contemporary War (New York: Oxford University Press, 2007), 8. 
the people of the RVN.”48 It goes on to delineate responsibility between regular military forces and territorial forces for the execution of activities against the enemy’s regular and irregular forces and pacification efforts (“liberation”.) Likewise, the RVNAF were supposed to be able to “demonstrate the achievement of social justice” to the people of the RVN, while being separate from the politics of Vietnam. ${ }^{49}$

The MACV planners addressed the importance of rapidly making progress in Vietnam by declaring “... [T]ime is running out!” The CSOP explored two operational concepts, one being that assessments of progress were to be made purely qualitatively and the other being that time had to be measured in equal importance to qualitative progression. Here, the MACV planners discussed the friction between the time required to achieve the desired end states and the time they realistically thought they would have to do this. MACV planners were unable to resolve the friction between the likelihood of a decades long struggle between North and South Vietnam and the time politically available to MACV to support these efforts. The result was that while MACV understood that "time was running out," they believed that for the RVN to survive, the US would realistically have to remain involved in Vietnam with tens of thousands of troops until the 1980s. The following chart depicts this.

${ }^{48}$ Headquarters MACV, The Combined Strategic Objectives Plan, 1970, 61. ${ }^{49}$ Ibid., 63. 


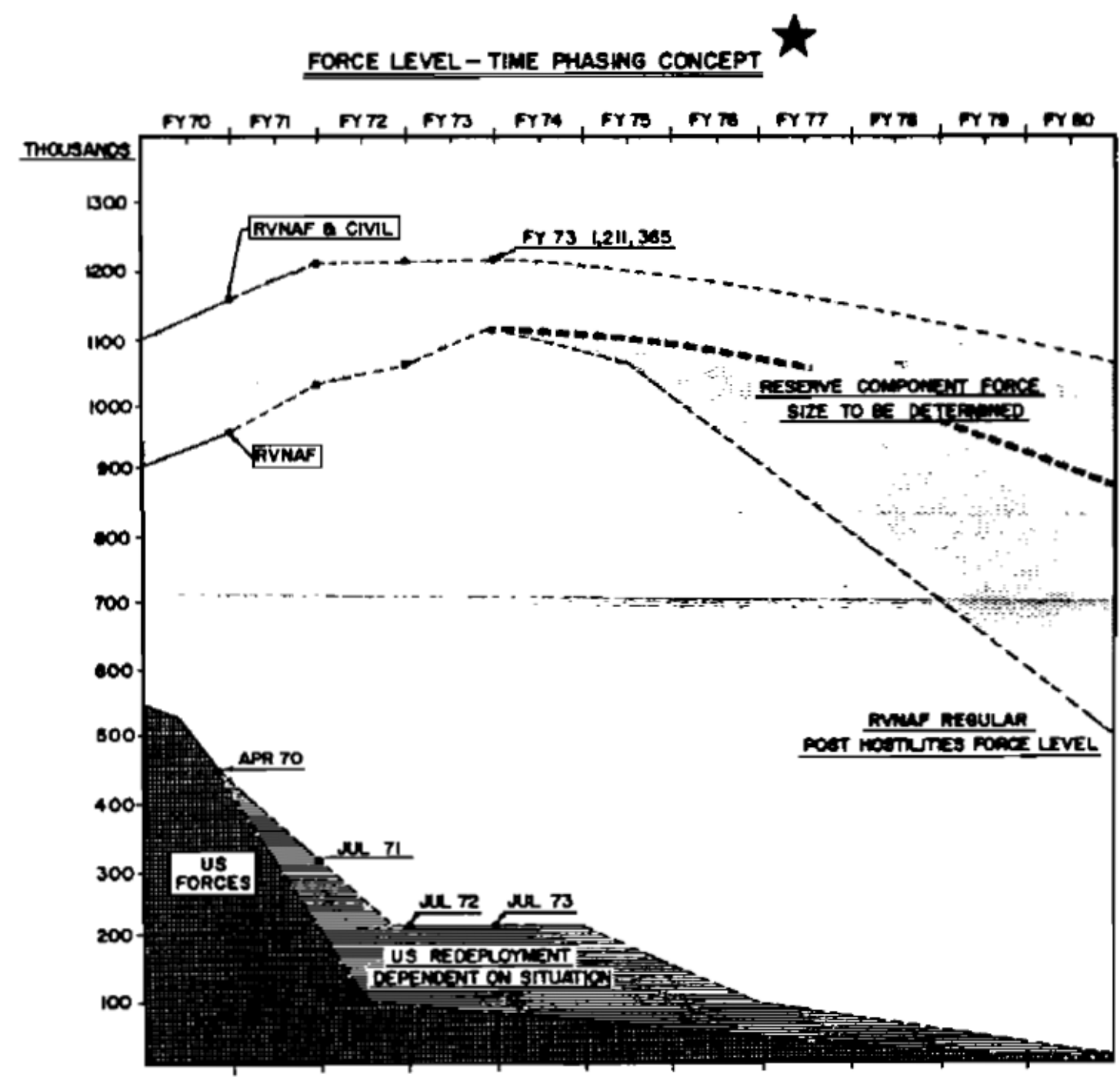

Figure 1. MACV and JGS planners forecast the need for a US troop presence in Vietnam into 1980. In the short term, they planned to have between 50,000 and 100,000 US troops in Vietnam until mid-1976.

Source: Headquarters MACV, The Combined Strategic Objectives Plan, 1970, Operational Planning and Directives, San Francisco: Headquarters MACV, 1970, 150.

The planners, primary consideration came down to US domestic opinion and Congressional patience for the progression of the war. They devoted significant analysis to the effects of then-upcoming domestic elections in the US, on their ability to continue to prosecute the war. This type of analysis on US domestic politics indicates that the US military was treading 
upon a slippery slope that threatened to violate its apolitical status by seeking to influence the US electorate.

Military involvement in domestic affairs has generally been sharply curtailed in the US from its inception. During the Cold War, Army intelligence worked extensively to identify domestic subversion and maintain population control. Military collection efforts were primarily oriented on antiwar demonstrations, going so far as to collect on "virtually every aspect of civilian protest politics." ${ }^{50}$ During the Vietnam War, the US military overreached in its domestic intelligence collection and analysis and sought to use this to influence domestic populations and government departments. This would later lead to several Congressional hearings and committees, bills put forth to limit military domestic intelligence, and an even greater lack of trust in the US military. ${ }^{51}$ The Army's domestic spying program was exposed in 1970 by journalist Christopher H. Pyle, resulting in laws now limiting the Department of Defense's (DOD) ability to conduct domestic intelligence gathering. There are also DOD regulations imposing self-limitation on the purpose and use of such intelligence, specifically DOD Directive 5240.01 that applies to DOD intelligence activities. ${ }^{52}$

The theme of politics governing the conduct of war was consistent throughout the CSOP nearly to the point of contradiction. While the document acknowledged the primacy of civil politics, it also devoted significant effort to define the then-current political environment in not

${ }^{50}$ Paul J. Scheips, In The Role of Federal Military Forces in Domestic Disorders, 19451992, by Paul J. Scheips, 369-400 (Washington DC: Government Printing Office, 2012), 377.

${ }^{51}$ Paul J. Scheips "Antiwar Demonstrations and Surveillance." In The Role of Federal Military Forces in Domestic Disorders, 1945-1992, by Paul J. Scheips, 369-400, (Washington DC: Government Printing Office, 2012).

52 Stephen Dycus, "The Role of Military Intelligence in Homeland Security." Louisiana Law Review, 2004, 779-807. 
only the RVN, but also in the US. The directives in the CSOP sought ways for the military to influence the political will of both domestic US and South Vietnamese politics.

The CSOP went on to describe how operations would be conducted using operational and intelligence planning considerations. The methodologies described thus far and through the remainder of this document were in keeping with the works of John J. McCuen and the theories he laid out in his book, “The Art of Counter-Revolutionary War: The Strategy of Counterinsurgency” published in $1966 .^{53}$ The comprehensive strategy McCuen laid out emphasized successful population control, extended small unit deployments, destruction of enemy base areas, the establishment of friendly base areas, and the creation of a "firm politicomilitary foundation.”54 McCuen’s work was specifically aimed at developing a methodology to defeat Maoist communist revolutionary tactics by examining those tactics and turning them in favor of the counter-revolutionary, in this case, the US and the RVNAF. One of the key components to McCuen's strategy was the establishment of a strong central governmental authority to coordinate all activities against revolutionary forces, which the CSOP 1970 clearly sought to support.

The CSOP itself was broken down into four parts. Each of these parts describes key aspects of the war as conceptualized by the MACV and JGS planners. The organization of the CSOP builds to describe clearly an operational approach within the confines of the current situation. The CSOP used terminology, defined throughout the document. It is important to

53 John J. McCuen was a retired US Army officer who wrote the "The Art of CounterRevolutionary War: The Strategy of Counterinsurgency,” published by St. Petersburg: Hailer Publishing in 1966, which laid out his philosophy regarding counter-revolution and provides a methodology for attempting to combat revolution. McCuen's theories were specifically oriented on countering communist insurgency based on the teaching of Mao Tse-Tung. McCuen had spent a significant portion of his career in the Far East and had served as an advisor and instructor with the RVNAF.

${ }^{54}$ Ibid., 324. 
understand the layering of terms and definitions MACV and JGS planners used in developing their concepts. This is important because this document intended to create a common mental framework and language for the coalition to accompany the new operational approach, which explains why much of it was written like an educational text. The concepts within the CSOP were not easily captured in hard metrics like body counts, so measuring effectiveness and performance would prove difficult. The end conditions described by MACV planners were directly applicable to the RVN first and then the US military and government second.

Part One of the CSOP describes the desired end conditions, by conceptualizing four key aspects of the conflict. These were further developed into what would commonly be referred to today as lines of effort (LOEs). These four LOEs were military, political, economic, and sociopsychological aspects of the conflict. The terms “National Objectives” and "National Policies" bounded the LOEs further. The term "National Objectives” was defined as: "Those fundamental aims, goals, or purposes of a nation -- as opposed to the means of attaining these ends - toward which a policy is directed and efforts and resources of the nation are applied.”55 This was essentially the description of a desired national end state for the RVN, which the CSOP further delineated temporally into ultimate, intermediate, and immediate objectives.

The ultimate objectives were those that described a fully realized end state. Both the intermediate and the immediate objectives are significant themselves, as they represent benchmarks forward toward the ultimate objectives and the desired end state. These objectives graduated in ambition from the immediate to the ultimate, defined by conditions on the ground but bounded by time. Only general time horizons were assigned to each, but this framework would allow commanders to apply resources against these objectives while conducting continuous assessment to determine the progress being made toward their goals.

55 Headquarters MACV, The Combined Strategic Objectives Plan, 1970, 10. 
The term "National Policy” was described as: “Governmental guidance at the national level; a broad course of action, selected from among alternatives and in the light of given conditions, to guide present and future commitments of resources toward achievement of an objective; may include specific or implied constraints." ${ }^{\text {"6 }}$ The national policies within the CSOP meant to provide the "how" when considering the manner in which the coalition sought to achieve the various national level objectives. This document provided national-level policies across the four LOEs, which were outlined in general before going into the specifics. The withdrawal of all foreign troops from the RVN was discussed as taking place in coordination with the withdrawal of communist forces from the same. However, it also addressed the "[u]nilateral redeployment of US forces." ${ }^{57}$ Unilateral withdrawal of US forces is considered completely separate from the withdrawal of the remainder of coalition forces from Vietnam. However, the CSOP identified the necessary conditions established as criteria that would permit US drawdowns. These conditions were generally dependent on the ability of the RVN to maintain its own territorial integrity. The CSOP listed three conditions that would permit the withdrawal of US forces: the capability of the Republic of Vietnam Armed Forces (RVNAF) to secure RVN territory, the progress of the Paris Peace Talks, and the level of communist activity. ${ }^{58}$ The final portion in the CSOP addressing the redeployment of US troops states that "No redeployment action will be taken which threatens those remaining Allied troops or which endangers attainment of the combined fundamental objective” which mirrored statements made by President Richard Nixon on his November 3, 1969 address to the American people. ${ }^{59}$ Between December 31, 1969

\footnotetext{
${ }^{56}$ Ibid., 10.

${ }^{57}$ Ibid., 26.

${ }^{58}$ Ibid., 26.

${ }^{59}$ Ibid., 27.
} 
and December 31, 1970, US troop commitments in Vietnam dropped from 480,000 to 280,000. By 1971, only 140,000 US troops remained in the RVN. ${ }^{60}$ The stated position of the Nixon administration was for a “...complete withdrawal of all US combat ground forces, and their replacement by South Vietnamese forces on an orderly scheduled timetable.”61

The withdrawal of US combat troops was already well underway by the time the CSOP 1970 was published. To accomplish the ultimate desired conditions, MACV and JGS planners developed four conceptual LOEs that were military, political, economic, and socio-psychological. Each of these was tied to temporal objectives (immediate, intermediate, and ultimate), the CSOP further described the "end conditions" necessary to achieve the overall objective. Throughout the CSOP, the military end conditions were the most developed and numerous. Of note, in general, the end conditions of each line of effort were primarily oriented on the enemy's ability to affect the government and people of the RVN, this reinforcing the shift towards "Vietnamization."

An examination of the "Immediate End Conditions" are most pertinent to the exploration of the effectiveness of the CSOP 1970 as this document was superseded annually. The timelines that were provided for the realization of the established end conditions were as follows: immediate objectives were to be achieved by the end of 1970, intermediate objectives were to be

${ }^{60}$ The withdrawal of US troops occurred more quickly than MACV and JGS planners had anticipated. At the time the CSOP was published planners believed they would still have approximately 100,000 US troops in the RVN until mid-1974 with troop's strength continuing a slight but steady decline until the early 1980's, Headquarters MACV, The Combined Strategic Objectives Plan, 197, 150.

${ }^{61}$ Richard Nixon, Public Broadcasting System, The American Experience, November 03, 1969, accessed September 11, 2014.

http://www.pbs.org/wgbh/americanexperience/features/primary-resources/nixon-vietnam/. 
accomplished in 1971, with the ultimate objectives being realized by 1975 or later. ${ }^{62}$ Based on the end conditions described, realizing the immediate end conditions would have been the primary focus of commanders for the next six to twelve months. Very few of the end conditions, though, were achievable with great rapidity. Progress along these lines would be better measured in months and years as opposed to weeks. The following graphic depicts MACV's concept for end condition achievement.

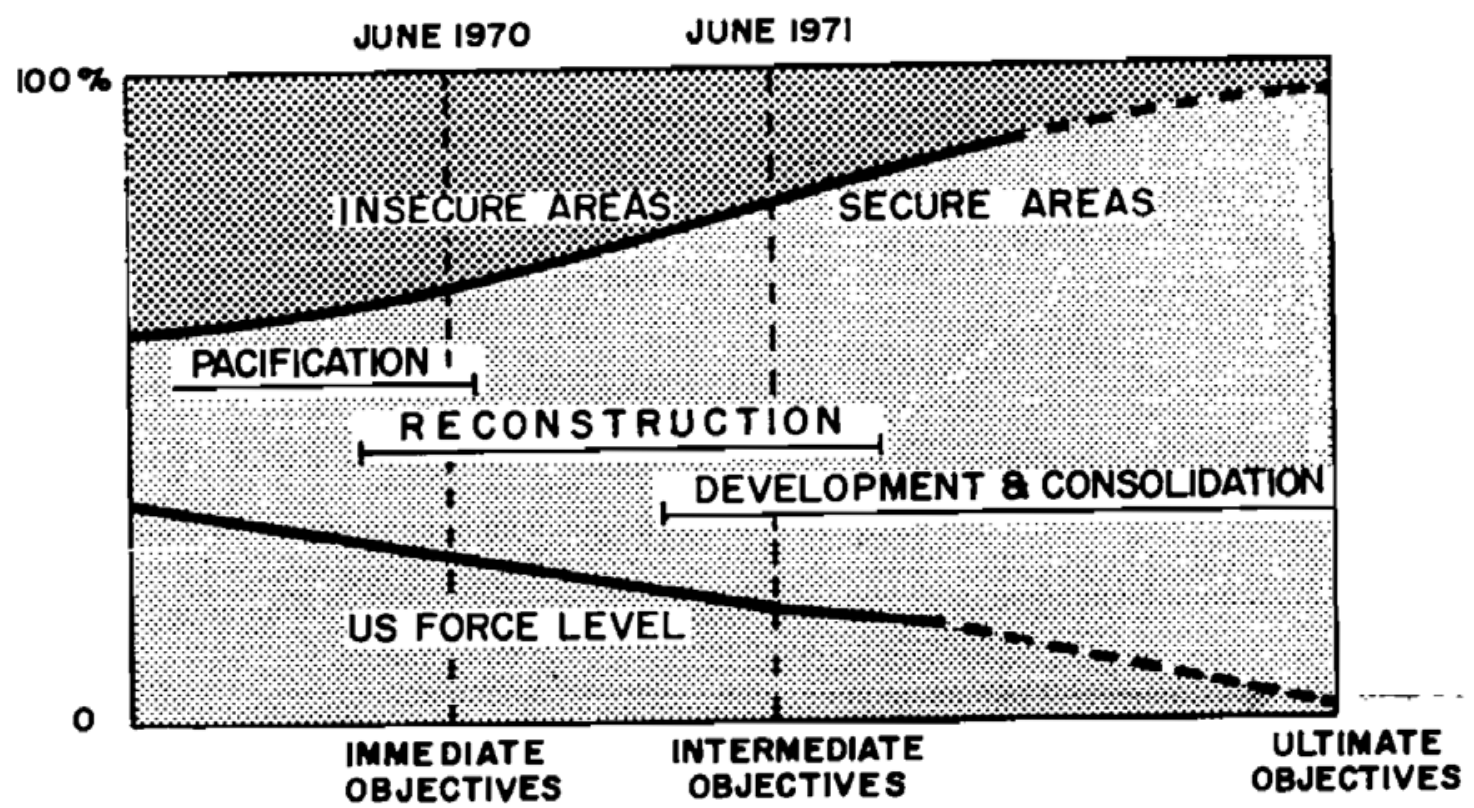

Figure 2. Graphic depiction of friendly operations and force flow as objectives are achieved.

Source: Headquarters MACV, The Combined Strategic Objectives Plan, 1970. Operational Planning and Directives, San Francisco: Headquarters MACV, 1970, 76.

The military end conditions cover a wide array of operations. Effects on enemy capabilities were covered in depth with a focus on limiting the ability of the enemy to influence

${ }^{62}$ The end conditions described for each of the temporal objectives (immediate, intermediate, and ultimate) were arranged in the CSOP in lists and are several pages in length. All four lines of effort (military, political, economic, and socio-psychological) were intended to support the fundamental RVN national objectives of "developing and preserving democracy, reforming society to achieve improved social justice, preserving the territorial integrity and independence of the RVN, and achieving peace”, Headquarters MACV, The Combined Strategic Objectives Plan, 1970, 17. 
the population of RVN through subversion and overt combat operations. In addition to enemy effects on the population, the desired capabilities of the RVNAF were also described here. Some of these conditions were that the “...RVNAF consistently are capable of defeating equivalent size units...ARVN units are operating in a mobile role in the Clearing Zones... Planning decisions have been made as the qualitative and quantitative means of completing the improvement and modernization of the RVNAF, and other security elements..." ${ }^{63}$ While some of the end conditions were easily measured, such as the quantity and effectiveness of enemy military activity around population centers and the neutralization of base areas, others were much harder to quantify. This is particularly the case where the CSOP described the desired end conditions for the development of the RVNAF. “Unity of Military Thought” among South Vietnamese security forces would have been particularly difficult for commanders to measure and even more difficult to support and develop.

Aside from the theme of population control and protection, the most significant thread running through the military end conditions focused on the ability and capability of the RVNAF. The combat effectiveness of indigenous security forces, their ability to operate independently of US support, and their ability to plan operations on their own were listed as key metrics to be assessed. Of interest is the inclusion of not only security force effectiveness but also the effectiveness of local-level GVN representatives “...to resolve administrative and tactical problems of enemy misuse of internal boundaries,” which speaks to a much broader approach to defeat the communist insurgency that required close coordination between the civilian government and the military. ${ }^{64}$ The military goals were ambitious but, when compared to the

${ }^{63}$ Headquarters MACV, The Combined Strategic Objectives Plan, 1970, 19. ${ }^{64}$ Ibid., 19. 
other LOEs, indicated that MACV's confidence in the RVNAF was growing and that the South Vietnamese security forces were becoming successful. ${ }^{65}$

This was not the case, however, when compared to the outlined political end conditions, which were not only those directly applicable to the theater of operations but to the US domestic population as well. The South Vietnamese General Staff and the MACV planners understood how eroding US public support would affect the war effort. The importance of US domestic support was captured in statements like this: "Two major types of US political considerations also affect the time phasing of the Combined Strategic Objectives Plan: a) electorate factors which determine the composition of the Congress, and b) budget factors which affect the allocation of resources for the Vietnam War." ${ }^{66}$ These sections clearly outlined ways MACV could influence and be influenced by the US civilian government and the will of the US people. The more unpopular the war became in the US, the less support the RVN would receive. However, creating conditions that meant to influence the American public to support the war could easily have be misconstrued as propaganda. Given the lack of confidence the American public had in the military by this time, evidenced by Pew Research data ${ }^{67}$, the CSOP stated that the, “...reduc[ing] internal US opposition to assisting the RVN, and increasing the international understanding of the US / GVN side of the struggle in SVN" was necessary to successfully prosecute the war. ${ }^{68}$

${ }^{65}$ Headquarters USMACV, United States Military Assistance Command, Vietnam Command History Volume II 1970, Compilation of reports and assessment (Saigon: Military History Branch, Office of the Secretary, Joint Staff, 1971), VII-98.

${ }^{66}$ Headquarters MACV, The Combined Strategic Objectives Plan, 1970, 65.

${ }^{67}$ Jodie T. Allen, Nilanthi Samaranayake, and James Albrittain, Jr. "Iraq and Vietnam: A Crucial Difference in Opinion", Pew Research Center, March 22, 2007, accessed October 11, 2014. http://www.pewresearch.org/2007/03/22/iraq-and-vietnam-a-crucial-difference-in-opinion/.

${ }^{68}$ Headquarters MACV, The Combined Strategic Objectives Plan, 1970, 19. 
The political end conditions echoed previous assessments concerning the state of the GVN, stating that, the government still must “... [demonstrate] significant stability, and capacity to improve efficiency.” This was due to the continued lack of confidence military planners had in the GVN's current ability to manage national affairs. ${ }^{69}$ While the RVNAF continued to increase in both capacity and capability, the government that it supported was developing at a much slower rate. At this point in the war, elections in the RVN were still not being held with any regularity. The people of RVN considered the GVN inefficient, corrupt, and generally ineffective. ${ }^{70}$

Modest immediate goals were set for the economic line of effort. Some of the goals included "relative freedom" along inland waterways and certain "lengths” of major highways. Rampant inflation was a significant issue for the RVN. Keeping inflation at thirty percent annually was an indicator of how unstable the RVN had become. Using ARVN pay scales as a measure of national income in the RVN gives an indication of the effects of inflation and the strain put on the population. Dr. Jeffrey J. Clarke, former Chief of Military History at the US Army Center of Military History noted that, “[b]etween 1964 and 1972 consumer prices in South Vietnam rose 900 percent and the price of rice rose 1400 percent, while incomes rose only about 300 percent for the officers and at most, 500 percent for the enlisted men.”71 The figure below shows how RVN currency rapidly lost its value in comparison to US dollars.

${ }^{69}$ Ibid., 19.

${ }^{70}$ Nguyen Cao Ky, How We Lost the Vietnam War (New York: Cooper Square Press, 2002), 112.

${ }^{71}$ Jeffrey J. Clarke, Advice and Support: The Final Years, The U.S. Army in Vietnam (Washington DC: Government Printing Office, 1988), 503. 


\begin{tabular}{|c|c|c|}
\hline \multirow{2}{*}{ Calendar Year } & \multicolumn{2}{|c|}{ Piasters per U.S. Dollar } \\
\hline & & 35 \\
\hline $1966 \ldots$ & & 80 \\
\hline 1967 & & 118 \\
\hline $1970 \ldots$ & & 285 \\
\hline $1972 \ldots \ldots \ldots$ & $\ldots \ldots \ldots \ldots$ & 420 \\
\hline $1974 \ldots \ldots \ldots$ & $\ldots \ldots \ldots \ldots$ & 560 \\
\hline $1975 \ldots \ldots \ldots$ & $\ldots \ldots \ldots \ldots$ & 700 \\
\hline
\end{tabular}

Figure 3. The above graphic shows the massive inflation and de-evaluation of the RVN piaster in comparison to the US dollar. This caused significant issues for the GRVN, particularly when it came to paying government employees and troops.

Source: Jeffrey J. Clarke, Advice and Support: The Final Years, The U.S. Army in Vietnam (Washington DC: Government Printing Office, 1988), 503.

Runaway inflation rapidly deteriorated the ability of the RVN to maintain its legitimacy.

As illustrated above, the rapidly declining real income of the military did nothing to help eliminate corruption. This inflation made the pay that the military and other government employees worth less, creating more incentive to steal and engage in activities considered corruption. The CSOP acknowledged this by referring to massive inflation as a "constraint" and stating that it, “... strikes with particular force at the fixed-salary military personnel and GVN administrators -virtually forcing many of them to be corrupt, as well as to a reduction in on-thejob effectiveness through the need to hold other jobs or engage in business ventures." ${ }^{72}$ Corruption and black marketeering thus became a major source of income for members of the RVNAF, almost to the point of necessity and served to erode further the effectiveness of the armed forces while at the same time depriving the central civilian government of much of its authority ${ }^{73}$ MACV's economic assessment indicated that this would only get worse and the RVN's economy would grow weaker as US personnel redeployed home. There was virtually no

\footnotetext{
72 Headquarters MACV, The Combined Strategic Objectives Plan, 1970, 57.

${ }^{73}$ Nguyen Cao Ky, How We Lost the Vietnam War, 101-116.
} 
plan to deal with this, other than for the GVN to reduce its spending while seeking other sources of revenue and international capitol. The RVNAF was by far the greatest expense of the RVN, with ammunition expenditures by the ARVN alone costing half the entire budget. ${ }^{74}$

Neither MACV nor State Department officials had much success affecting government reform to fight inflation and corruption. ${ }^{75}$ The RVNAF remained the primary form of governance across much of South Vietnam, bringing with them the black marketeering and corruption that would further undermine the civilian government and damage the economy. The South Vietnamese military had created a shadow economy that had become self-perpetuating out of necessity. The economic issues in South Vietnam had become intimately intertwined and inseparable from the military.

The CSOP addressed the "socio-psychological” aspects of the war, by acknowledging that coalition efforts had been counterproductive and had not significantly blunted the enemy's attempts at subversion. In the section regarding the strategic estimate of the situation in the RVN, the CSOP stated:

As a result of general failure of military commanders and troops to fully understand pacification and its strategic significance, combined with enemy capabilities to attack at his initiative, and lack of sufficient integration of the intelligence effort, security of the individual citizen of South Vietnam cannot be realistically guaranteed. This situation is rendered even less palatable in countering the threat through continued sporadic RVNAF and FWMAF troop misconduct toward Vietnamese civilians. Further, there is lack of fully effective ARVN logistics support, lack of an appropriate RVNAF force structure and lack of appropriate tactics to support the strategy -- when related to potentially available RVNAF resources. ${ }^{76}$

${ }^{74}$ Headquarters MACV, The Combined Strategic Objectives Plan, 1970, 187.

${ }^{75}$ Jeffrey J. Clarke, Advice and Support: The Final Years, The U.S. Army in Vietnam, 504.

${ }^{76}$ Headquarters MACV, The Combined Strategic Objectives Plan, 1970, 55. 
MACV sought to counteract the negative trends along the socio-psychological line of effort by increasing education, improving relations between the US and RVN, improving “combined activities,” and encouraging resettlement of refugees into populated areas. Creating a system of national education was seen as a way to counter communist subversion and foster a national identity and narrative supportive of the RVN. Education was one of the top two priorities of the South Vietnamese people. ${ }^{77}$ Since the end of the colonial period, the number of South Vietnamese with access to education had increased dramatically. US involvement in the war in Vietnam added massive funding to the development of the RVN's national school system. According to author Orin Schwab:

By 1967, secondary-school enrollment had jumped another 800 percent to 432,000 students. As of the 1969-1970 school year, more than 630,000 high school students were enrolled in the Republic of Vietnam, a 1,200 percent increase in just fifteen years. By 1970, 25 percent of high school-age students in South Vietnam were in secondary schools. ${ }^{78}$

The MACV and JGS planners who authored the CSOP understood and attempted to articulate the complexity of the environment in which they were operating, and the breadth and depth required in planning and coordination to achieve the desired future conditions. Critical assumptions that they built into their planning were directly linked to the political will of the American electorate and the political will of the communists to sustain or escalate the war. MACV and the JGS needed American politicians to give them more time and continued support in terms of money, troops (combat or advisory), materiel, and government support for at least another decade for their plan to work as drafted. Additionally, communist forces would have to continue to fight as infiltrators and insurgents; if they moved back to large-scale conventional

${ }^{77}$ Nguyen Anh Tuan, America Coming to Terms: The Vietnam Legacy (Bloomington: Xlibris Corporation, 2010), 197.

${ }^{78}$ Orin Schwab, A Clash of Cultures: Civil-military Relations During the Vietnam War (Westport: Praeger Security International, 2006), 105. 
warfare some of the baseline assumptions of the CSOP would be invalidated, requiring another major reframing of the problem.

The LOEs within the CSOP outlined MACV's operational approach and showed the challenges within each. MACV would be responsible for the creation of a competent RVNAF, the development stable governance that could administer ethnically diverse nation at war, growing an economy that could sustain the people of RVN, the GVN, and their armed forces, while also creating a national identity that fostered unity and inclusion that effectively countered the messages of communist propaganda. All of these efforts would entail significant challenges to be realized. Ultimately, it would fall to the soldiers and commanders on the ground, at the Field Force level and below, to turn this approach into reality. 


\section{Corps and Division Military Operations in support of the Combined Strategic Objectives}

Plan, 1970

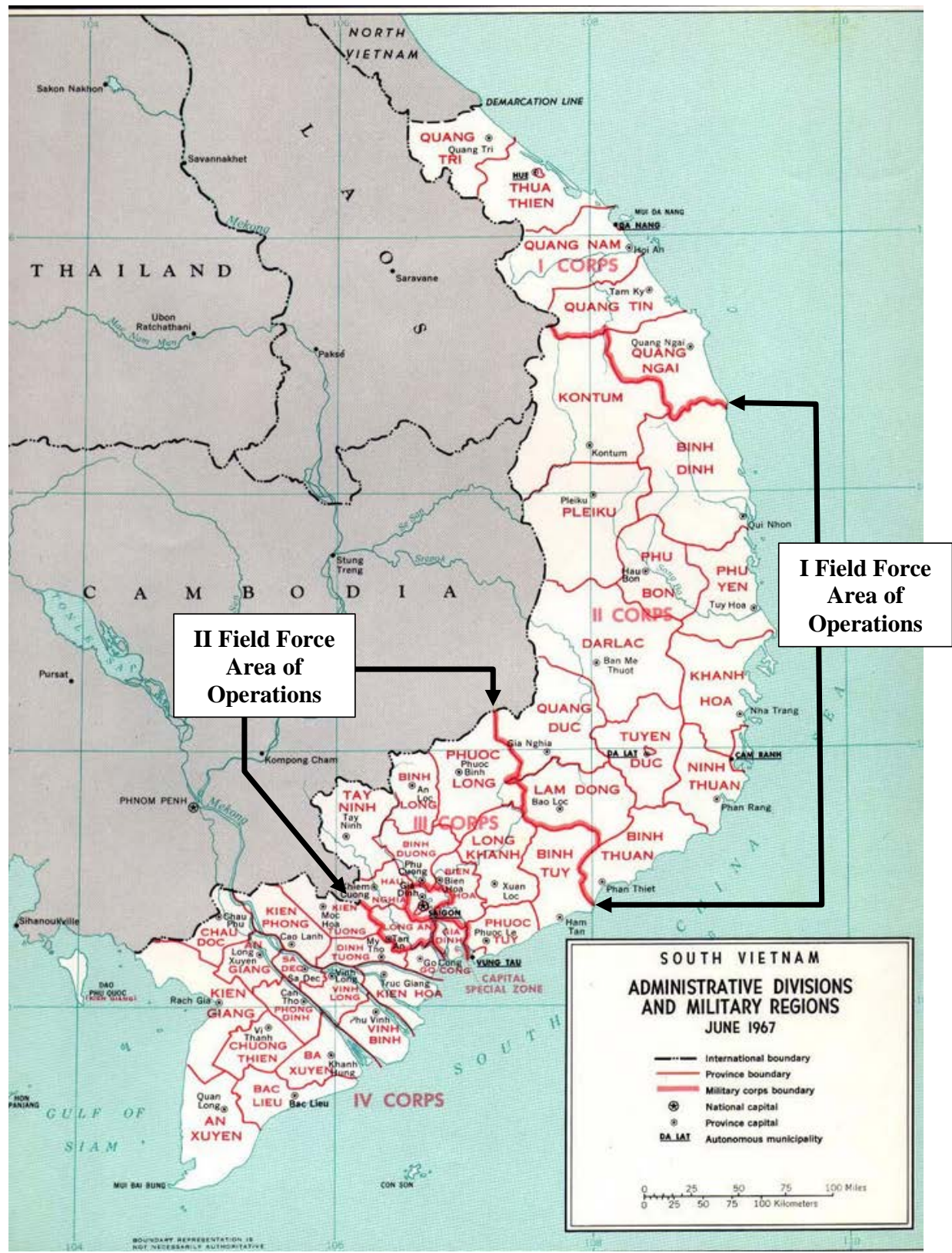

Figure 4. Map depicting the Corps Tactical Zones (CTZ), provincial, and national boundaries of the RVN. The numerical designations for CTZs do not match the numerical designation for the various corps level commands operating in those areas. I Field Force operated in the II CTZ and II Field Force operated in the III CTZ as indicated above.

Source: Commons, "Southvietmap", Licensed under Public domain via Wikimedia, Wikimedia Commons. January 10, 2006, accessed August 02, 2014. http://commons.wikimedia.org/wiki/File:Southvietmap.jpg\#mediaviewer/File:Southvietmap.j pg. 
This section will examine quarterly reports from MACV, I, and II Field Force Headquarters from 1968 through early 1971, as a means to review the effects of the CSOP 1970 on operations. Informing this will be the secondary review of numerous division and brigadelevel quarterly reports from the same period. In general, CSOP 1970 does not appear to have caused a major operational shift across the RVN. The adoption of the operational approach described in the CSOP was more a result of the operational environment, particularly the threat, than the result of the concise top-down guidance provided by MACV planners. Additionally, the approach described by the CSOP was already well-developed and in execution by I Field Force prior to 1970, while II Field Force was still unable to adjust significantly their approach by late 1970.

In 1970, the RVN was broken into four military districts, or Corps Tactical Zones (CTZ), with the headquarters of each was designated a Field Force. By 1970, there was very little US presence in the IV CTZ around the Mekong Delta, this region being almost completely secured by RVNAF. The III CTZ contained the capitol of Saigon and was heavily defended by a mix of US and South Vietnamese divisions. The III and IV CTZ were composed of the regions with the greatest economic and political value to the war effort.

I CTZ in the far north of the RVN was significant as it was the only military district that shared a boundary with communist North Vietnam. Both US and South Vietnamese units manned the DMZ between the two halves of Vietnam. By the intelligence estimates of MACV, this region continued to face large enemy troop concentrations. ${ }^{79}$ The II CTZ, the largest of all the districts, was composed of the central highlands and defended by both US and RVNAF divisions. It had a

${ }^{79}$ Headquarters MACV, MACV Quarterly Evaluation 01APR-30JUN69, Quarterly assessment of operations and effects, (Saigon: Headquarters MACV, 1969). 
dispersed population and like I CTZ had much less economic and political importance than the resource rich south.

The methods the Field Force commands used to record and report their activities to MACV are important. Given that the CSOP outlined a new operational approach, reporting should reflect new measures of success and updated formats. The CSOP was not broken down into efforts that translate neatly to traditional military staff functions. For MACV properly to assess progress along each LOE towards the multitude of end conditions already outlined in the CSOP, unit reporting at least at the corps level should have reflected a change; some portion of the Field Force quarterly reports should clearly report status and assessment that nested with the CSOP. However, this was not the case.

The corps and division-level quarterly reports followed generally the same format. They were organized as extended memorandums that are laid out along the lines of conventional US Army staff functions, arranged in a manner similar to an operations order. The reports all start with intelligence (G2) reports and estimates then transition to in-depth reporting on completed, ongoing, and planned operations. Logistics activity (G4) is then described followed finally by personnel and administrative activity (G1). In addition to these traditional staff section reports, there are additional sections included individually for emphasis. After the personnel section there are sections specifically for artillery, engineers, signal, the inspector general's office, the office of the judge advocate, and the information office.

Of particular significance to this study is the section that covers "Civil Operations and Revolutionary (or Rural depending on the year of the report) Development Support.” This covers the unit's involvement and support to the CORDS program, which was the organization under MACV that was responsible for coordinating all civilian and military agencies directly involved 
in the pacification effort. ${ }^{80}$ President Lyndon Johnson created CORDS to displace the communist insurgency by creating pro-GVN local ties at the village and hamlet level, while incorporating military and civilian efforts from the US and RVN. The CORDS program was the result of the marrying of the US Office of Civil Operations (OCO) to the organizational and command structure of MACV. This allowed the incorporation of more military forces and resources that which OCO had had previous access, in an effort to speed up pacification. In order to place emphasis on the importance of CORDS, President Lyndon Johnson personally appointed the leader of the program, made him deputy to the MACV Commander, and bestowed upon him the rank of ambassador. This was a program deemed of very high importance to the Commander in Chief, however the level of emphasis placed on this effort was not shared uniformly across MACV's subordinate commands. ${ }^{81}$

I Field Force quarterly reports generated both before and after the publication of CSOP 1970 average about eighty pages in length. Specifically examining I Field Force reports published in May of both 1968 and 1970, shows an increase in the emphasis placed on the support of CORDS programs. While sections in both pre-CSOP 1970 and post-CSOP 1970 reports are approximately thirteen pages in length, the reports immediately following the publication of the CSOP show much greater clarity and depth than those preceding them. Overall, the CORDS section of I Field Force’s quarterly reports from 1970 reflects the MACV commander's intent to emphasize governance and the US policy of Vietnamization. By contrasting the 1969 and 1970 reports, it is clear that US forces were doing less unilaterally or by directing the efforts of the GVN, such as in the execution of the Village Self Development (VSD) program.

${ }^{80}$ Spencer C. Tucker, The Encyclopedia of the Vietnam War: A Political, Social, and Military History (Santa Barbara: ABC-CLIO, LLC, 2011), 209.

${ }^{81}$ Andrew F. Krepinevich Jr., The Army and Vietnam (Baltimore: Johns Hopkins University Press, 1986), 215-232. 
The VSD replaced the Village Self Help (VSH) program during this period. Both programs dealt with the provision of funds to South Vietnamese communities for economic development and public works. Aid provided by the VSH program, though, was outside the village budgetary process and was determined to be counterproductive in developing the civic activity among the South Vietnamese necessary to counter the communist insurgency. ${ }^{82}$ Local power brokers and leaders had manipulated previous programs like the VSH for their own benefit as opposed to pursuing the projects that would yield the greatest benefit to their communities. The VSD was intended to “... [support] two major pacification objectives: the strengthening of village/hamlet government and the stimulation of the rural economy." 83 The centralization of the previous self-help program was thought to be unresponsive to the needs of the people in the communities its projects were intended to benefit, due to the frequent lack of community involvement in the decision making process. These programs were controlled generally at levels above the actual village or hamlet that they were intended to help; provincial and district level leaders determined what projects would be completed. Partly because of this, the previous program did not allow the local governments to become any more proficient in the management of their finances or to foster increased participation in local politics and civic activity ${ }^{84}$ Measures of success for the VSD included the amount of community input and participation in the process itself (a qualitative look at the process, versus the previous quantitative measure of projects completed). ${ }^{85}$ The movement towards more local authority in the disbursement of funds began to

${ }^{82}$ The Vietnamese Village Rural Development Division Community Development Directorate CORDS, The Vietnamese Village 1970 Handbook for Advisors (San Francisco: Translations and Publications Branch Management Support Directorate CORDS, 1970), 31-55.

${ }^{83}$ Ibid., 49.

${ }^{84}$ Ibid., 50.

${ }^{85}$ Ibid., 31-55. 
take root in late $1969 .{ }^{86} \mathrm{Up}$ to this point, the villages had sent all taxes to the national government in Saigon.

Civic ties developed through this initiative were meant to create links between the people and their government, while keeping governance as local as possible. In this respect, it was very successful. By 1970, the villages themselves managed ninety-five percent of the VSD funds within I Field Force's area of operations, with the remaining five percent not yet able to manage their own funds due to a lack of education and accountability being Montanyard villages, whose funds were still being managed by the district. ${ }^{87}$ The organizers of the VSD were generally from the GVN in the form of political cadres with US advisors, showing an increased level of effectiveness at the district and local level that was not in existence only a year before.

However, there is an indication that the local civilian government may not have been as stable as it first appeared. The report states that “[m]any provinces report increased activity in VSD projects and participation by ARVN forces." ${ }^{88}$ The ARVN were still in control of the majority of civic activity. Regional Forces (RF) and Popular Forces (PF) soldiers were the primary audience being training at GVN civic action schools, as village administrators and

${ }^{86}$ Ibid., 31-55.

${ }^{87}$ Headquarters, I Field Force, Operational Report-Lessons Learned Headquarters First Field Force Vietnam, Period Ending 30 April 1970, Quarterly Operational Report-Lessons Learned document (San Francisco: Headquarters, I Field Force, 1970), 38.

${ }^{88}$ Ibid., 42. 
counter-insurgents, so they could increasingly assume this role from the ARVN. ${ }^{89}$ The RF / PF were primarily intended to be a security function subordinate to local leaders; they also took on aspects of direct local leadership as well, due to the administrative and civics training the South Vietnamese military received coupled with their placement amongst the population. ${ }^{90}$ However while this effort strengthened the military's knowledge base, it could also serve to undermine the effort to create a strong civilian government being served and protected by the RVNAF. It was, a step forward from having US or ARVN troops themselves coordinating civic functions of local governments as was evident from the 1969 reports on civic activity. ${ }^{91}$

MACV put great emphasis on the destruction of the Vietnamese Communist Infrastructure (VCI). ${ }^{92}$ The most prominent of these programs was Phoenix, or Phung Huong, the coalition effort to destroy the communist revolutionary cadres operating throughout the RVN. The 1970 reports go into some detail explaining the decline in "neutralization” numbers being due to the Tet holiday and new criteria used to classify what qualified a VCI-associated person as being neutralized. This emphasis on the Phoenix program was not due to CSOP 1970. The 1969

${ }^{89}$ Regional Forces (RP) and Popular Forces (PF) were two distinct elements of local security efforts undertaken to allow the ARVN to disengage in direct population security and allow them to secure borders and find and destroy enemy formations, a duty that was still largely with US units. Regional Forces were generally under the direction of the provincial chiefs where Popular Forces were directly responsible to the hamlet and village leaders; however, by 1970 these forces both fell under the ARVN while maintaining their local focus, Jeffrey J.Clarke, Advice and Support: The Final Years, The U.S. Army in Vietnam, 37.

${ }^{90}$ Gregory A. Daddis, No Sure Victory: Measuring U.S. Army Effectiveness and Progress in the Vietnam War, 116.

${ }^{91}$ Headquarters, I Field Force, Operational Report-Lessons Learned Headquarters First Field Force Vietnam, Period Ending 30 April 1970, 58.

${ }^{92}$ Gregory A. Daddis, No Sure Victory: Measuring U.S. Army Effectiveness and Progress in the Vietnam War, 151. 
operational reports from I Field Force, show the greatest growth and effort in this area with the 1970 reports merely continuing to emphasize a program deemed of great value. ${ }^{93}$

Other CORDS programs, though, show markedly less activity or interest by 1970 . Reporting on the operations of the Revolutionary Development Cadre (RDC) or Rural Development Cadre shows a distinct decrease from 1969 to 1970. The RDC program was specifically intended to provide support to governance at the local level. However, since the Central Intelligence Agency (CIA) was charged with its development, it could also be used to counter communist VCI cadres and gather intelligence. Based on the operations conducted by these groups in 1969, the RDC groups were operating very much like their communist counterparts. Far from merely being civilian advisors on best practices for village leaders, they were organized into paramilitary groups who were fighting the VC for control of the villages and hamlets. While direct action was not their primary role, they were capable of self-defense. Regardless, the number of RDC teams declined between 1969 and 1970, indicative of the decreased emphasis on this effort. The 1970 reports conclude the narrative on the RDC in eleven lines of text, whereas the 1969 reports devote over a full page on this aspect of CORDS alone, indicating greater emphasis. The fact that RDC teams had declined and that all reporting indicates that they were being attrited due to VC attacks is another indicator that rural South Vietnam was less secure then it appeared. ${ }^{94}$ Programming specifically to foster good governance was directly

${ }^{93}$ Headquarters, I Field Force, Operational Report-Lessons Learned Headquarters First Field Force Vietnam, Period Ending 30 April 1970, Quarterly Operational Report-Lessons Learned document (San Francisco: Headquarters, I Field Force, 1970), 39; Headquarters, I Field Force, Operational Report - Lessons Learned, Period Ending 31 July 1970, Report of operations in combat (San Franciso: Headquarters, I Field Force, 1970), 24; Headquarters, I Field Force, Operational Report-Lessons Learned Headquarters First Field Force Vietnam, Period Ending 30 April 1969, Quarterly Operational Report-Lessons Learned document (San Francisco: Headquarters, I Field Force, 1969), 64.

${ }^{94}$ Ibid., 39 and 63. 
in line with the guidance given in CSOP 1970, however it appears that the RDC program had stagnated or begun to fail. This program was exceptional in that it showed negative growth from the 1969 to 1970 reports. With the exception of the RDC program, all other CORDS efforts had been expanded of more heavily supported. Eventually, much of the training supplied to the RDC units was incorporated into training for the ARVN, lessening the need for a separate RDC role. ${ }^{95}$

There was no less support for CORDS programs in 1970 than in 1969; however, the reporting from 1970 is more concise and showed an incredible amount of forward progress in just one year. I Field Force operations appeared to have been little effected by the publication of CSOP 1970. The operational approach adopted by I Field Force as early as 1969 was already in keeping with that laid out in the CSOP 1970, but, this was not the case with II Field Force.

Compared to I Field Force’s reporting on non-military operations, II Field Force’s reporting shows a marked difference. There is very little emphasis on reporting CORDS-related activities by II Field Force indicating a mirrored emphasis in execution. Fewer than four pages are devoted to reporting on actions that were not classified as combat operations or those operations directly in support of combat, indicating a significantly lesser institutional effort being applied to non-combat operations. Very little qualitative or even quantitative information was provided. In general, reporting indicates improvement over the last reporting period, though, this is not backed up by qualifying statements of progress and in general, there is far too little information to provide a clear understanding of what II Field Force was doing in regards to noncombat operations. It seems that the II Field Force staff's was focus remained on combat as opposed to pacification, which may not be too far from the truth. In the intelligence assessments of enemy capabilities found in both Field Force reports from roughly the same reporting periods

${ }^{95}$ Jeffrey J. Clarke, Advice and Support: The Final Years, The U.S. Army in Vietnam (Washington DC: Government Printing Office, 1988), 235. 
the enemy faced in the III CTZ (II Field Force’s area of operations) was a much greater threat than what I Field Force faced.

The 1969 reports for I Field Force indicate that fewer than half of the provinces within their area of operations had enemy forces capable of attacking in "multi-battalion” strengths. In the remainder, the communists were only capable of mounting attacks with battalion-sized elements or merely conducting attacks by fire and harassment. ${ }^{96}$ The 1969 reports from II Field Force painted a much grimmer picture. Their assessment of the enemy’s capabilities within III CTZ was that, "[t]he enemy is capable of launching multi-battalion sized ground attacks throughout the corps zone. Attacks may be supported by rockets and mortar fire and sapper action." ${ }^{97}$ In addition to this, their assessment also stated that the enemy was capable of launching these attacks "simultaneously." 98 Due to the more capable enemy opposing II Field Force, they appear to have been unable to adopt a strategy in line with the guidance provided by the CSOP, placing an increased emphasis on the political, socio-psychological, and economic LOEs. While I Field Force was making significant progress along the non-military LOEs described in MACV's new operational approach, II Field Force had been unable to create the time and space necessary to do the same.

${ }^{96}$ Headquarters, I Field Force, Operational Report-Lessons Learned Headquarters First Field Force Vietnam, Period Ending 30 April 1969.

${ }^{97}$ Headquarters, II Field Force, Operational Report-Lessons Learned Headquarters First Field Force Vietnam, Period Ending 30 September 1969, Quarterly Operational Report-Lessons Learned document (San Francisco: Headquarters, II Field Force, 1969).

${ }^{98}$ Ibid., 22. 


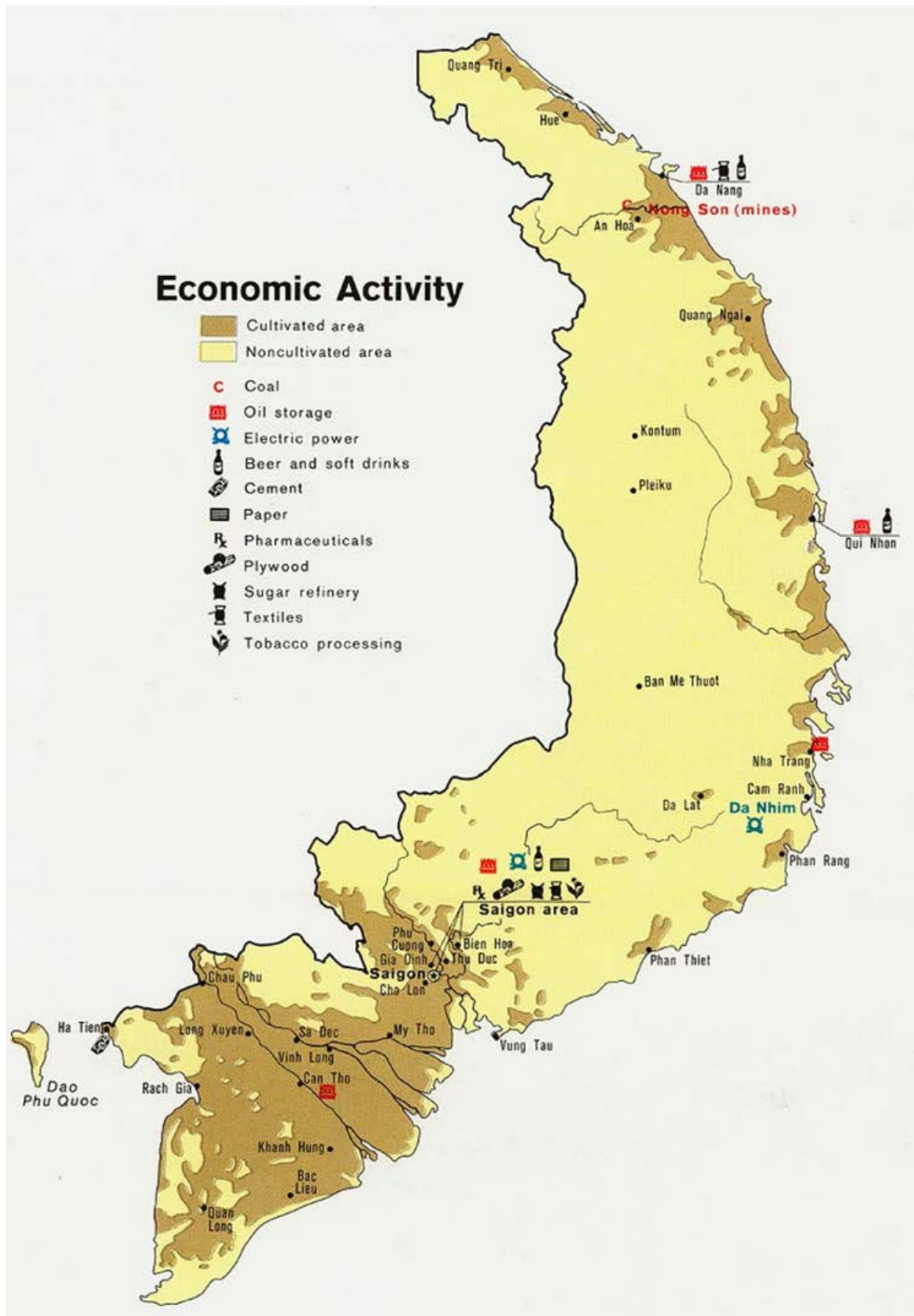

Figure 5. Map depicting economic activity and farming in the RVN. This shows why the southern portion of the RVN was vital to both the communists and the GVN.

Source: Texas Tech University, The Vietnam Center and Archive. 2014, accessed August 02, 2014. http://www.virtual.vietnam.ttu.edu/cgibin/starfetch.exe?5Gjk1@wZoTcUzgBkbDZllaZh9B291FtripzdlrKa1BodADH89AhcEO0Sx pf8fAmkijf53Mu9K3as@VUVljSoi0pJmTdeEujN/MAP12060206.pdf. 
Despite the greater enemy threat in the III CTZ, it is surprising that II Field Force did not have a greater emphasis on governance and CORDS than is evident in their pre-CSOP 1970 reports. Not only was the majority of national economic activity located within the III CTZ (as indicated in Figure 5), but the RVN capitol, Saigon, was there as well. Post-CSOP 1970, the II Field Force reports have a much greater emphasis on non-military activity and CORDS support. The number of pages devoted to these operations had doubled and the information within was more detailed. However, there remains a very heavy weight assigned to the development and recruiting of local and regional security forces. This emphasis on continued security force development existed even as the report acknowledged, “...dramatic improvement in the security situation...” which was echoed by the Field Force intelligence assessments that state that enemy forces are unable to attacking in anything greater then a battalion-sized element. ${ }^{99}$ Overall, II Field Force’s post-CSOP 1970 reporting shows a vastly different outlook on the III CTZ. While they still remained combat-focused (particularly after just having conducted the largest portion of the Cambodian Invasion), II Field Force operations were very much focused on the protection of the South Vietnamese population and the development of the GVN. ${ }^{100}$

Reports of friendly operations during the 1969-1970 reporting periods did not indicate a radical change from one year to the next in the sheer volume of enemy contact. Common throughout these reports was that the security situation generally improved. However, intelligence

${ }^{99}$ Headquarters, II Field Force, Operational Report-Lessons Learned, Quarterly Operational Report-Lessons Learned document, Period Ending 31 July 1970, San Francisco: Headquarters Second Field Force Vietnam, 1970.

100 The Cambodian Invasion was a series of major ground operations undertaken by Coalition forces between April through July 1970. These operations involved three US divisions, six ARVN divisions, and naval and air forces attacking along a broad front, in an attempt to disrupt communist ground lines of communication by destroying stock piles, base areas, and command and control nodes in Cambodia, Brigadier General Tran Dinh Tho, The Cambodian Incursion, Campaign Analysis (Washington, DC: U.S. Army Center of Military History, 1979). 
estimates of enemy strength remained approximately equivalent. The II Field Force reports reflected a twenty percent decrease in the number of enemy infantry regiments in their area of responsibility, but at the same time reported an almost thirty percent increase in the number of separate enemy battalions. Communist forces were reported as both more combat ready and effective then they had been the previous year. ${ }^{101}$

I Field Force’s reports reflect total enemy numbers that showed a net decrease by over two-thousand fighters, from 54,000 to 52,000, a four percent decrease from 1969 to $1970 .{ }^{102}$ I Field Force, however accounted for enemy combat power differently than II Field Force. II Field Force counted units of battalion and regimental size, while classifying these units by various measures of combat effectiveness. II Field Force reported the number of enemy they believed they faced in total, without classifying enemy combat power into conventional type units. They instead, classified them as NVA, local forces, administrative facilitators, guerilla forces, and communist infrastructure cadre. They noted heavy losses of enemy persons in all categories but

${ }^{101}$ Headquarters, II Field Force, Operational Report - Lessons Learned, Period Ending 31 January 1969, Report of operations in combat (San Francisco: Headquarters, I Field Force, 1969), 4-24; Headquarters, II Field Force, Operational Report - Lessons Learned, Period Ending 31 January 1970, Report of operations in combat (San Francisco: Headquarters, II Field Force, 1970), 4-21; Headquarters, II Field Force, Operational Report - Lessons Learned, Period Ending 31 October 1970, Report of operations in combat (San Francisco: Headquarters, II Field Force, 1970), 6-22; Headquarters, II Field Force, Operational Report-Lessons Learned, Period Ending 30 April 1969, Quarterly Operational Report-Lessons Learned document (San Francisco: Headquarters Second Field Force Vietnam, 1969), 3-22; Headquarters, II Field Force, Operational Report-Lessons Learned, Period Ending 31 July 1970, Operational Report-Lessons Learned document (San Francisco: Headquarters II Field Force, 1970), 7-27.

${ }^{102}$ Headquarters, I Field Force, Operational Report-Lessons Learned Headquarters First Field Force Vietnam, Period Ending 30 April 1970, Quarterly Operational Report-Lessons Learned document (San Francisco: Headquarters, I Field Force, 1970), 1-10; Headquarters, I Field Force, Operational Report - Lessons Learned, Period Ending 31 July 1970, Report of operations in combat (San Francisco: Headquarters, I Field Force, 1970), 1-9; Headquarters, I Field Force, Operational Report-Lessons Learned Headquarters First Field Force Vietnam, Period Ending 30 April 1969, Quarterly Operational Report-Lessons Learned document (San Francisco: Headquarters, I Field Force, 1969), 1-13. 
the NVA. The reason why their enemy combat power analysis did not show greater than a four percent drop was due to massive reinforcement from the NVA to make up for the loss of irregular forces. $^{103}$

Enemy activity and capabilities were the deciding factors that allowed Coalition forces to shift from an enemy focused "search and destroy” operational approach to governance and development focus areas extolled in the CSOP 1970. I and II Field Forces faced significantly different levels of enemy threat within their assigned CTZs. II Field Force should have showed the highest emphasis on economic development and governance given that their area of operations contained the economic heartland and capital city of the RVN; however the constant threat of brigade-sized enemy attacks occurring simultaneously across the CTZ, though, prevented this. Likewise I Field Force could have been expected to have a much higher enemy focus being that their CTZ incorporated massive stretches of undefended border, the mountainous central highlands, and vast stretches of coast, this was not case. While communist forces may not have known the specifics of the MACV plan, they seemed to understand the problem the Coalition faced as well as the MACV planners did.

${ }^{103}$ Headquarters, II Field Force, Operational Report - Lessons Learned, Period Ending 31 January 1969, 4-24; Headquarters, II Field Force, Operational Report - Lessons Learned, Period Ending 31 January 1970, 4-21; Headquarters, II Field Force, Operational Report Lessons Learned, Period Ending 31 October 1970, 6-22; Headquarters, II Field Force, Operational Report-Lessons Learned, Period Ending 30 April 1969, 3-22; Headquarters, II Field Force, Operational Report-Lessons Learned, Period Ending 31 July 1970, 7-26. 


\section{Analysis \& Conclusion}

The CSOP, 1970 did not herald a radical shift in operational approach, nor did it achieve the desired future conditions outlined within. MACV and JGS planners built those future conditions on several critical assumptions that would prove to be false, and based on their own analysis, unrealistic. Subordinate commands were not able to adopt fully the adjusted operational approach as operations and reporting showed little change after the publication of the CSOP.

Field Force commands had either already embraced an increased focus on governance and development or they had not, and the enemy got a vote as to how MACVs subordinate commanders focused their efforts.

The CSOP was the first document of its kind to incorporate planners from MACV and the JGS in an attempt to create an overarching concept for the execution of the war in Vietnam. It provided great analytical depth based on sound theoretical principles. However, it was fatally disconnected from US domestic politics, which created discontinuities within its own pages as well. The operational approach based on this fatal disconnect, rendered all resulting analysis and planning a moot point; the plan developed was not feasible as it would not be acceptable to the American electorate due to the decade required to execute it. Additionally, MACV's subordinate commands were unable to embrace fully the CSOP's operational approach due to enemy pressure and the steady withdrawal of US support and resources. The concepts within the CSOP were difficult to turn into detailed and actionable plans by corps and division commands who were in contact with a tenacious enemy and partnered with an unstable RVN. Ultimately, these fatally flawed assumptions coming from a military attempting to achieve objectives while ignoring the domestic politics of the conflict would manifest in the complete and utter defeat of the RVN in 1975. When viewed through the lens of the Clausewitzian Trinity of "passion, reason, and 
chance” the element of "reason” represented by military necessity was at odds with the "passion" of the people. ${ }^{104}$

The sheer volume of the CSOP may have been a weakness. Two hundred pages of analysis, guidance, charts, and matrices delivered in hard copy may have been just too much for field commands to interpret properly and fully translate into an actionable plan, especially when some sections seem to provide conceptual contradiction to others, particularly in regards to time. This may have been most apparent in the more conceptual sections describing intent versus the more detailed planning and analysis provided in other sections. “[T]ime is running out!,” was stated emphatically in the "Phases In Time And Space” section, that immediately followed the “Commander's Concept” paragraphs; however, the further the CSOP went from commander's concept and intent to more detailed planning, the greater the discord between the two. By page 150, the CSOP began ignoring the very timelines earlier passages stressed, showing a forecasted requirement for a significant US troop presence into the 1980s. ${ }^{105}$ The planners of the CSOP understood the war effort was limited by rapidly failing domestic support for the war, making projection of continued US troop presence over ten years in the future, a poor requirement on which to plan and seemed wholly unrealistic. Other sections describe philosophical and operational concepts that may have required significant effort to make understood and actionable by military commanders unfamiliar with micro and macro-economic principles and both local and national politics.

Overall, though, there was certainly enough guidance throughout the CSOP to allow commanders to both understand the MACV commander's intent and immediately begin to act on it. It provided both the impetus to achieve short-term end conditions and adjust the operational

\footnotetext{
${ }^{104}$ Carl Von Clausewitz, On War (Princeton: Princeton University Press, 1984), 86.

${ }^{105}$ Headquarters MACV, The Combined Strategic Objectives Plan, 1970, 64 and 150.
} 
approach of the subordinate commands. The challenge for the corps and division level units was to operationalize the CSOP and force institutional change on both US and RVNAF while still fighting an enemy that was by no means defeated. Given this, the quarterly reports provided by the divisions and corps should have immediately reflected a change in operational approach, with post-CSOP 1970 reports showing a significant increase on the efforts of subordinate commands to conduct civil-military operations and provide support to the RVNAF. There should have been a decreased emphasis on destroying enemy main force units and operations should have taken on an increased aspect of decentralization. Large battalion and brigade-named operations should have been the exception rather than the rule. However, this was not the case. Unit reporting from I and II Field Forces reflects very little change from 1969 (pre-CSOP) to early 1971 (post-CSOP). The reporting formats remained nearly identical and did not specifically quantify progress along any of the four LOEs described by the CSOP.

In the analysis of enemy options, the CSOP fell short. According to MACV's threat assessment, even while communist activity had declined in the RVN during this time, the enemy was still actively pursuing the defeat of the RVNAF and the toppling of the Saigon government. ${ }^{106}$ Field reports showed that despite continuing losses, communist military capability was rapidly reconstituted. ${ }^{107}$ None of this could have been a surprise to the MACV staff who predicted this in their analysis of the conflict. The continuous struggle forecasted by MACV was correct. However, at the time of its publication, the CSOP 1970 did not address the possibility of a major invasion by conventional communist forces. The most likely enemy courses of action

\footnotetext{
${ }^{106}$ Headquarters MACV, The Combined Strategic Objectives Plan, 1970, 197.

${ }^{107}$ Reports from both I Field Force and II Field Force for the $3^{\text {rd }}$ Quarter Fiscal Year 1970 indicated that communist military forces were rapidly regenerating from losses. This allowed the communists forces to maintain pressure on the RVN, Headquarters, II Field Force, Operational Report-Lessons Learned, Period Ending 31 July 1970, 7-27; Headquarters, I Field Force, Operational Report - Lessons Learned, Period Ending 31 July 1970, 1-9.
} 
assessed by MACV and JGS involved continued subversive attempts to support insurgent activity, not a movement back to large-scale conventional ground combat. The caveat included in this analysis was as follows: "the communist strategy, policies and tactics will adapt to meet changing situations the ultimate communist goal will continue to be victory in South Vietnam.” 108 While this does not directly account for a full-scale DRV invasion, it does leave the possibility open. The insurgency and communist subversion were seen as the primary threat to the existence of the RVN, with DRV conventional forces in a supporting role. While this was true in 1970, it would not remain so as the operational environment continued to change, and the DRV was presented with new opportunities to end the conflict in their favor.

Just as the analysis of the enemy proved shortsighted, the same can be said for the CSOP planners' understanding of the friendly situation. “Time” was stressed repeatedly as being a critical factor to coalition success; however, the time horizons outlined in the CSOP stretched out to over the next decade. The commitment the CSOP described was akin to the US commitment in the Republic of Korea following the Korean War, with tens of thousands of US troops continuing to assist in the security and survival of the RVN into the 1980's. While US political support was deemed to be of great importance, the MACV planners divorced their plan from the effects of US domestic opinion on the war. While it did take into account the perceived need to build support for the war domestically, it was highly unlikely that this would become manifest given that President Richard Nixon was elected because he, “...sold his ‘secret plan’ for ending the Vietnam War to a war-weary electorate.” ${ }^{109}$ Investing political capital in stirring American passions for a limited war in South East Asia would be wasteful or even futile. By 1970, the extreme unpopularity of the Vietnam War was irreversible.

${ }^{108}$ Headquarters MACV, The Combined Strategic Objectives Plan, 1970, 9.

${ }^{109}$ J. Edward Lee Haynsworth and H. C. Toby, Nixon, Ford and the Abandonment of South Vietnam (Jefferson: McFarland and Company Inc, 2002), 53. 
The development of distinct LOEs was a valuable tool in the description of the operational environment and the application of resources against the achievement of the objectives associated with each. The inclusion of time factors in the accomplishment of immediate, intermediate, and ultimate objectives was likewise an excellent conceptual tool with which to provide subordinate commanders. By delineating the LOEs, describing the objectives associated with each, and providing rough time horizons, corps and division commanders were well equipped to understand what they were working towards with the time left to them in Vietnam. However, it does not appear that the publication of this document had any radical effects on how the corps and divisions at the operational and tactical level were fighting the war. Based on the operational and tactical level reporting from 1969 (pre-CSOP) with those up to early 1971 (post-CSOP) there was little difference that could be directly attributed to a change in operational approach. Major adjustments in posture and focus, if any, were more dependent on external factors beyond the commanders' control like the level of enemy activity in their area and the steady withdrawal of combat troops from their commands. As a whole, support for CORDS in general was better developed, but this likewise did not appear to be the result of the CSOP 1970. Rather, the-nearly-across-the-board improvement in agriculture, education, governance, VCI neutralization, and security force quantity and quality seems to be the product of an evolutionary execution of MACV's counterinsurgency strategy prior to the CSOP, coupled with ongoing Vietnamization policies.

The political LOE in particular may have been overly ambitious in the time available to MACV. The creation of “Tu Tuong,” a strong and unifying national identity, takes generations to develop. ${ }^{110}$ While MACV had a plan to help create this, it would have taken time that they did not

${ }^{110}$ Peter L. Berger and Thomas Luckmann, The Social Construction of Reality: A Treatise on the Sociology of Knowledge (Garden City: Doubleday, 1966). 
have. The development of Tu Tuong was to be, “... [t]hrough indoctrination, education, and democratic seminars... [that] [t]he unified thought to be shared by the Vietnamese people comes from their Constitution." ${ }^{111}$ This is somewhat contradictory to the "innate love of freedom" mentioned earlier in the same section of the CSOP, indicated the imposition of an inorganic thought process on the people of the RVN. It should be noted, that the goals of the communists in Vietnam were nearly identical to those of the GVN itself. The RVN and the DVR were delivering shades of the same argument to the people of Vietnam; the methodologies described were a RVN version of the communist revolutionary cadres that were at work fostering dissention and subversion within their borders.

Assumptions based on time ultimately condemned MACV's plan to failure. Specifically assumptions related to how much time the American public would give MACV to execute its plan and how the enemy would use the time available to them. Conceptually, MACV planners realized that their time was growing short and immediate gains would have to be manifest within 18 months or they risked losing everything they had achieved; the American people did not support the war, President Nixon had been elected to end it, and the US was rapidly pulling out of Vietnam. As the CSOP was translated from a conceptual to a more detailed plan it lost this understanding and the urgency that it imparted, by stretching planning timelines beyond what was politically possible. The continued lengthy timeline for US involvement in Vietnam may have been militarily feasible and necessary for the survival of the RVN, but it was disconnected completely with the domestic US politics of the war.

${ }^{111}$ Headquarters MACV, The Combined Strategic Objectives Plan, 1970, 123. 


\section{Bibliography}

Allen, Jodie T., Nilanthi Samaranayake, and James Albrittain, Jr. "Iraq and Vietnam: A Crucial Difference in Opinion." Pew Research Center. March 22, 2007, accessed October 11, 2014. http://www.pewresearch.org/2007/03/22/iraq-and-vietnam-a-crucial-difference-inopinion/.

Andrade, Dale and James H. Wilbanks. "CORDS/Phoenix Counterinsurgency Lessons from Vietnam for the Future." Military Review, 2006: 77-91.

Blackwell Publishing. A Companion to the Vietnam war. Malden: Blackwell Publishing Company, 2002.

Castle, Timothy N. At War in the Shadow of Vietnam: US Military Aid to the Royal Lao Government 1955-1975. New York: Columbia University Press, 1993.

Center of Military History, United States Army. Historical Perspectives of the Operational Art. Fort McNair: Government Printing Office, 2005.

Chancellor, George W. Strategic Hamlet Program; New Life Development Program; Revolutionary Development Program. Recommended adjustment to Vietnam Pacification, Fort Leavenworth: US Government, 1967.

Clarke, Jeffrey J. Advice and Support: The Final Years, The U.S. Army in Vietnam. Washington DC: Government Printing Office, 1988.

Clausewitz, Carl Von. On War. Princeton: Princeton University Press, 1984.

Colonel Wayne W. Grigsby, Jr. "Integrated Planning: The Operations Process, Design, and Military Decision Making Process." Military Review, 2011: 28-35.

Commons, "Southvietmap". Licensed under Public domain via Wikimedia. Wikimedia Commons. January 10, 2006, accessed August 02, 2014.

http://commons.wikimedia.org/wiki/File:Southvietmap.jpg\#mediaviewer/File:Southvietm ap.jpg.

Daddis, Gregory A. No Sure Victory: Measuring U.S. Army Effectiveness and Progress in the Vietnam War. New York: Oxford University Press, 2011.

Dycus, Stephen. "The Role of Military Intelligence in Homeland Security." Louisiana Law Review, 2004: 779-807.

Echevarria, Antulio J. II. Clausewitz and Contemporary War. New York: Oxford University Press, 2007.

Eggleston, Michael A. Exiting Vietnam: The Era of Vietnamization and American Withdrawal Revlealed in First-Person Accounts. Jefferson: McFarland and Company Inc., Publishers, 2014.

Ellis, J.W. and M.B. Schaffer. Three Months In Vietnam - A Trip Report; The Paramilitary War. Analysis of efforts to neutralize VCI, Santa Monica: Rand Corporation, 1967.

Gibbons, William Conrad. The U.S. Government and the Vietnam War: Executive and Legislative Roles and Relationships, Part IV: July 1965-January 1968. Princeton: Princeton University Press, 1995.

Gibson, James William. The Perfect War: Technowar in Vietnam. New York: Atlantic Monthy Press, 1986. 
Gravel, Mike, Noam Chomsky, Howard Zinn. The Pentagon Papers: The Senator Gravel Edition. Boston: Beacon Press, 1971.

Gregor, William J. "Military Planning Systems and Stability Operations." Prism, 2010: 99-114.

Haas, Richard. War of Necessity, War of Choice: A Memoir of Two Iraq Wars. New York: Simon and Schuster, 2009.

Haynsworth, J. Edward Lee and H. C. Toby. Nixon, Ford and the Abandonment of South Vietnam. Jefferson: McFarland and Company Inc., 2002.

Headquarters, Department of the Army. Army Doctrine Reference Publication 5-0, The Operations Process. Washington, DC: Government Printing Office, 2012.

-. Field Manual 3-24, C1, Insurgencies and Countering Insurgencies. Washington, DC:

Government Printing Office, 2014.

-. US Department of the Army Doctrine Reference Publication 3-0, Unified Land Operations. Washington, DC: Government Printing Office, 2012.

Headquarters MACV. Commander's Summary of the MACV Objectives Plan. Commander's Summary, Saigon: HQ MACV, 1969.

-. MACV Quarterly Evaluation 01APR-30JUN69. Quarterly assessment of operations and effects, Saigon: Headquarters MACV, 1969.

-. The Combined Strategic Objectives Plan, 1970. Operational Planning and Directives, San Fransico: Headquarters MACV, 1970.

—. United States Military Assistance Command, Vietnam Command History Volume II 1970. Compilation of reports and assessment, Saigon: Military History Branch, Office of the Secretary, Joint Staff, 1971.

Headquarters, 101st Airborne Division (Airmobile). Operation Report - Lessons Learned, Period Ending 30 April 1971. Report of combat operations, San Franciso: Headquarters, 101st Airborne Division (Airmobile), 1971.

Headquarters, 1st Cavalry Division (Airmobile). Operational Report - Lessons Learned 1st Cavalry Division (Airmobile) Period Ending 30 April 1970. Report of combat operations, San Francisco: Headquarters, 1st Cavalry Division (Airmobile), 1970.

Headquarters, 1st Infantry Division. Operational Report of 1st Infantry Division, for Period Ending 31 January 1970. Report of Combat Operations, Headquarters, 1st Infantry Division, 1970.

Headquarters, Americal Division. Operational Report- Lessons Learned, for Period Ending 15 October 1971. Report of combat operations, San Franciso: Headquarters, Americal Division, 1971.

-. Operational Report - Lessons Learned, Period Ending 30 April 1970. Report of combat operations, San Franciso: Headquarters, Americal Division, 1970.

Headquarters, I Field Force . Operational Report-Lessons Learned Headquarters First Field Force Vietnam, Period Ending 30 April 1970. Quarterly Operational Report-Lessons Learned document, San Francisco: Headquarters, I Field Force, 1970.

-. Operational Report-Lessons Learned Headquarters First Field Force Vietnam, Period Ending 30 April 1969. Quarterly Operational Report-Lessons Learned document, San 
Francisco: Headquarters, I Field Force, 1969.

—.Headquarters, I Field Force. Operational Report - Lessons Learned, Period Ending 31 July 1970. Report of operations in combat, San Francisco: Headquarters, I Field Force, 1970.

—. Senior Officers Debriefing Report, dated 31 December 1970. Debriefing from outgoing commanding general, I Field Force, San Franciso: Headquarters, I Field Force Vietnam, 1970 .

Headquarters, II Field Force. Operational Report - Lessons Learned, Period Ending 31 January 1969. Report of operations in combat, San Fransico: Headquarters, I Field Force, 1969.

—. Operational Report - Lessons Learned, Period Ending 31 January 1970. Report of operations in combat, San Fransico: Heaquarters, II Field Force, 1970.

—. Operational Report - Lessons Learned, Period Ending 31 July 1970. Report of operations in combat, San Franciso: Headquarters, II Field Force, 1970.

-. Operational Report - Lessons Learned, Period Ending 31 October 1970. Report of operations in combat, San Fransico: Headquarters, II Field Force, 1970.

—. Operational Report-Lessons Learned, Period Ending 30 April 1969. Quarterly Operational Report-Lessons Learned document, San Francisco: Headquarters Second Field Force Vietnam, 1969.

—. Operational Report-Lessons Learned, Period Ending 31 July 1970. Operational ReportLessons Learned document, San Francisco: Headquarters II Field Force, 1970.

Headquarters, XXIV Corps. Operational Report - Lessons Learned, Period Ending 31 July 1970. Report of operations in combat, San Franciso: Headquarters, XXIV Corps, 1970.

Hunt, Ira A. Jr. Losing Vietnam: How America Abadoned Southeast Asia. Lexington : The University of Kentucky Press, 2013.

Ienaga, Saburo. The Pacific War, 1931-1945. Tokyo: Iwanami Shoten, 1968.

Joint Staff. Joint Publication 3-0, Joint Operations. Suffolk: Government Printing Office, 2011.

—. Joint Publication 5-0, Joint Operation Planning. Suffolk: Governement Printing Office, 2011.

Joint Staff, J-7, Joint Staff and Coalition Warfighting. Planner's Handbook for Operational Design, Version 1.0. Suffolk: Government Printing Office, 2011.

Krepinevich, Andrew F. Jr. The Army and Vietnam. Baltimore: Johns Hopkins University Press, 1986.

Ky, Nguyen Cao. How We Lost the Vietnam War. New York: Cooper Square Press, 2002.

Larsen, LTG Stanley Robert and BG James Lawton Collins, Jr. Allied Participation in Vietnam. Washington, DC: Government Printing Office, 1985.

Luckmann, Peter L. Berger and Thomas. The Social Construction of Reality: A Treatise on the Sociology of Knowledge. Garden City: Doubleday, 1966.

McCuen, John J. The Art of Counter-Revolutionary War. St. Petersburg: Hailer Publishing, 1966.

Nation Master. NationMaster.com. June 20, 2014, accessed June 20, 2014. http://maps.nationmaster.com/country/vm/1.

Nixon, Richard. Public Broadcasting System, The American Experience. November 03, 1969, accessed September 11. 2014. 
http://www.pbs.org/wgbh/americanexperience/features/primary-resources/nixonvietnam/.

Scheips, Paul J. "Antiwar Demonstrations and Surveillance." In The Role of Federal Military Forces in Domestic Disorders, 1945-1992, by Paul J. Scheips, 369-400. Washington DC: Government Printing Office, 2012.

Schwab, Orin. A Clash of Cultures: Civil-military Relations During the Vietnam War. Westport: Praeger Security International, 2006.

Shaw, John M. The Cambodian Campaign. Lawrence: University Press of Kansas, 2005.

Sorley, Lewis. A Better War: The Unexamined Victories and the Final Tragedy of America's Last Years in Vietnam. Orlando: Harcourt, Inc., 1999.

—. Vietnam Chronicles: The Abrams Tapes. Lubbock: Texas Tech University Press, 2004.

Strachan, Hew. Clausewitz's On War: A Biography. New York: Grove Press, 2007.

Summers, Harry G. On Strategy: A Critical Analysis of the Vietnam War. New York: Random House Publishing, 1982.

Texas Tech University. The Vietnam Center and Archive. 2014, accessed August 02, 2014. http://www.virtual.vietnam.ttu.edu.

The Vietnamese Village Rural Development Division Community Development Directorate CORDS. The Vietnamese Village 1970 Handbook for Advisors. San Francisco: Translations and Publications Branch Management Support Directorate CORDS, 1970.

Tran Dinh Tho, Brigadier General. The Cambodian Incursion. Campaign Analysis, Washington, DC: U.S. Army Center of Military History, 1979.

Tuan, Nguyen Anh. America Coming to Terms: The Vietnam Legacy. Bloomington: Xlibris Corporation, 2010.

Tucker, Spencer C. The Encyclopedia of the Vietnam War: A Political, Social, and Military History. Santa Barbara: ABC-CLIO, LLC, 2011.

Walton, C. Dale. The Myth of Inevitable US Defeat in Vietnam. New York: Frank Cass Publishers, 2002.

West, Andrew. Vietnam's Forgotten Army: Heroism and Betrayal in the ARVN. New York: New York University Press, 2008.

Wiest, Andrew. Rolling Thunder in a Gentle Land: The Vietnam War Revisited. Long Island City: Osprey Publishing Ltd, 2006.

Wilbanks, James H. The Tet Offensive: A Concise History. New York: Columbia University Press, 2007.

—. Vietnam War: The Essential Reference Guide. Santa Barbara : ABC-CLIO, 2013. 